„FOLIA BIBLIOLOGICA” (2019), VOL. LXI

DOI: $10.17951 / \mathrm{fb} .2019 .61 .33-62$

Antoni Krawczyk

Uniwersytet Marii Curie-Skłodowskiej w Lublinie

https://orcid.org/0000-0003-0713-8611

\title{
KOLEKCJE BIBLIOTECZNE I MUZEALNE PRZEMIESZCZONE Z NIEMIEC PO II WOJNIE ŚWIATOWEJ W ZBIORACH ROSYJSKIEJ BIBLIOTEKI PAŃSTWOWEJ W ŚWIETLE PUBLIKOWANYCH KATALOGÓW MUZEUM KSIĄŻKI ${ }^{1}$
}

\begin{abstract}
Streszczenie: W Muzeum Książki Rosyjskiej Biblioteki Państwowej w Moskwie znalazły się kolekcje biblioteczne i muzealne przemieszczone z Niemiec po II wojnie światowej w ramach restytucji za zniszczone dobra kulturalne na okupowanych przez Niemcy terytoriach ZSRR. Obejmują one zbiory Muzeum Książki i Pisma w Lipsku (Deutsches Buch und Schriftmuseum in Leipzig) oraz Biblioteki Krajowej Saksonii w Dreźnie założonej w XVI wieku przez elektora Augusta I. Od czasu zakończenia wojny aż do pierestrojki jako trofea wojenne były one otaczane największą tajemnicą. Po jej uchyleniu rozpoczęto nad nimi badania naukowe. Rezultatem tego jest seria wydawnicza „Коллекции Российской государственной библиотеки”, w ramach której opublikowano dotychczas cztery katalogi: 1. Каталог художесвеннчх переплетов собр ания Карла Бехера; 2. Каталог набивных тканей собрания Роберта Форрерба; 3. Каталог инкунабулов и палеотипов собрания Генрихха Клемма; 4. Каталог переплетов Якоба Краузе и мастеров его круга (cz. 1, cz. 2, następna jest w opracowaniu). W prowadzonych analizach zawartości każdego z nich badacze poświęcają uwagę manuskryptom, inkunabułom, paleotypom oraz starodrukom. Omawiają też zawartość kolekcji tkanin z Lipska.
\end{abstract}

Słowa kluczowe: Rosyjska Biblioteka Państwowa w Moskwie, Muzeum Książki i Pisma w Lipsku, Biblioteka Krajowa Saksonii w Dreźnie, książki-trofea wojenne

1 Autor niniejszego artykułu od lat prowadzi korespondencję mailową z kierownikiem Muzeum Książki przy Rosyjskiej Bibliotece Państwowej w Moskwie dr Tatianą A. Dołgodrową i jako jeden z nielicznych w kraju, a może nawet jedyny, posiada pięć opracowanych przez Muzeum Książki tomów opisujących oprawy książek sprowadzonych do ZSRR z Niemiec po II wojnie światowej. 


\title{
The Library and Museum Collections Taken from Germany after the Second World War in the Resources of Russian State Library
}

\begin{abstract}
In the Book Museum of the State Library of USRR there were found museum and library collections which were taken from Germany after the Second World War in the name of the restitution for destroyed cultural assets. It concerned collections of Museum of Books and Types of Leipzig and the Land Library of Dresden founded by the elector August I in the $16^{\text {th }}$ century. As the war trophies until the period of perestroika they were covered by the greatest secrecy. After the removal of confidentiality, there were started scientific researches in this regard. The publication entitled "Коллекции Российской государственной библиотеки" is the results of those studies. In addition to it, 4 catalogs were elaborated: 1. Каталог художесвеннчх переплетов собрания Карла Бехера; 2. Каталог набивных тканей собрания Роберта Форрерфа; 3. Каталог инкунабулов и палеотипов собрания Генрихха Клемма; 4. Каталог переплетов Якоба Краузе и мастеров его круга (part 1, part 2, and next one in the preparation). Analysing each of these catalogs, the author pays attention to manuscripts, incabulas, paleotypes and old prints. Moreover, he describes the exhibits of textiles imported from Leipzig.
\end{abstract}

Keywords: The Russian State Library, Museum of Books and Types of Leipzig, The Land Library of Dresden, Books war trophy

Po II wojnie światowej, w latach 1945-1946, do ZSRR, a zwłaszcza do Państwowej Publicznej Biblioteki ZSRR im. W.I. Lenina w Moskwie (obecnie Rosyjska Biblioteka Państwowa - RBP; Российская государственная библиотека - РГБ), trafiło wiele książek zrabowanych przez hitlerowców na obszarach Związku Radzieckiego zajętych po inwazji w 1941 r., jak również w innych krajach, m.in. w wyniku działalności Sztabu Operacyjnego Rosenberga (Einsatzstab Reichsleiter Rosenberg - ERR), organizacji kierowanej przez Alfreda Rosenberga. Książki te składowano na terytorium Rzeszy, jak też Austrii i Czech. Wkraczająca na te tereny Armia Czerwona przejmowała książki pochodzące z ZSRR w ramach restytucji, zaś obce tytułem rekompensaty za zniszczone przez nazistów dobra kultury na swoim terytorium. Ponadto anektowała wiele książek z bibliotek oraz eksponatów muzealnych znajdujących się na zajmowanych terenach Rzeszy. Wśród tego typu zdobyczy były książki z Lipska oraz Drezna, o czym będzie mowa w dalszej części rozważań. Książki te nazywano trofiejnymi (mрофейньми).

Do czasów tzw. pierestrojki w ZSRR obowiązywała klauzula najwyższej tajemnicy na temat książek trofiejnych ${ }^{2}$. Pierwszym, który odważył się uchylić jej rąbka,

2 P. Kennedy Grimsted, The Odyssey of the Turgenev Library from Paris, 1940-2002. Books as victims and trophies of war, Amsterdam 2003; eadem, Twice plundered, but still not home from the war. The fate of three Slavic libraries confiscated by the Nazis from Paris, „Solanus” 2002, vol. 16, s. 39-76; eadem, Dwukrotnie zrabowane i nadal z dala od ojczyzny. Losy trzech bibliotek słowianskich przejętych przez nazistów w Paryżu, „Archeion” 2003, t. 106, s. 47-84; eadem, (П. Гринстед Кеннеди), Трофейные книги из Западной Европы: Дорога в Минск через Ратибор (Рацибуж), 
był dziennikarz Jevgeni Kuzmin. Na łamach „Литературной Газеты” zamieścił dwa artykuły. Pierwszy z 18 września 1990 r. (nr 38) zatytułowany Тайна церкви в Узком wskazywał, że ponad 200 tysięcy książek trofiejnych sprowadzonych z Niemiec do ZSRR po II wojnie światowej, w tym starych druków przekazanych radzieckiej Akademii Nauk, jest magazynowanych „z gołębimi odchodami” i gnije w pomieszczeniach opuszczonej cerkwi. On też ujawnił, że w 1947 r. oglądał dokument, w którym było napisane, że Państwowa Biblioteka ZSRR im. Lenina w Moskwie przyjęła około 200 tysięcy książek w językach angielskim, francuskim oraz innych, wśród których znajdowały się też woluminy z rosyjskiej Biblioteki im. I. Turgieniewa w Paryżu. Było to pierwsze oficjalne stwierdzenie w Rosji o anektowaniu książek z tej biblioteki ${ }^{3}$. Natomiast w drugim artykule z 2 listopada 1991 r. zatytułowanym Bвıести [...] уничтожить [...] спрятать... poruszył zagadnienie przywiezionych do ZSRR archiwów. Wtedy zaczęto też mówić w Rosji o celowym niszczeniu tego typu książek, z czym można było się spotkać w obszernym przypisie do referatu Mikołaja D. Kortelewa o tytule Плач о погибели русской библиотеки. Nadmieniał w nim o niszczeniu książek z Biblioteki im. I. Turgieniewa ${ }^{4}$. Z relacji Marii Evgrafiewny Samojłowej dowiadujemy się również, że w Kijowie zniszczono kilka książek dostarczonych tam z Ukraińskiej Biblioteki im. S. Petlury w Paryżu5.

W latach 90. ubiegłego stulecia czasopismo kulturalno-historyczne „Наше Наследие” zaczęło publikować artykuły o zdobyczach książkowych. Adrian Rudomino, syn Margarity Rudomino oddelegowanej do Berlina w 1945 r. w randze podpułkownika - bibliotekarza, a zarazem dyrektora Wszechrosyjskiej Państwowej Biblioteki Literatury Zagranicznej w Moskwie (WPBLZ; Всероссийской государственной библиотеки иностранной литературы - ВГБИЛ), w celu wysyłania z Niemiec do ZSRR eszelonów książek zamieścił w tym czasopiśmie (nr 32/1994) informację o losie tych książek pod tytułem Пол бека в плену, zaś Oleg Borodin wraz z Tatianą Dołgodrową ogłosili w nim (nr 12/1994) artykuł Коллекиия Немечқкого музея книги и шрифта в собрании Российской государственной библиотеки. Następnie w numerze 32 (1997) tego czasopisma Dołgodrowa opu-

\footnotetext{
[в:] Матэрыялы Трэиіх Міжнар. Кнігазнаўчых чытанняў „Кніга Беларусі: Повязь часоў” (Мінск, 16-17 верасня 2003 г.), склад. Т.I. Рошчына, Мінск 2005, s. 39-90; A. Krawczyk, Studia nad ksiażkami przemieszczonymi z Europy do ZSRR po II wojnie światowej, [w:] O etosie książki. Studia z dziejów bibliotek i kultury czytelniczej, red. T. Wilkoń, Katowice 2017, s. 99-123.

3 P. Kennedy Grimsted, op. cit., s. 15.

${ }^{4}$ Ibidem, s. 85; zob. też Н.В. Котрелев, Плач о погибели русской библиотеки, [в:] Редкие книги и рукописи. Изучение и описание. Материаль Всесоюзного совещания заведующих отделами редких книг и рукописей библиотек вузов. Ленинград, 24-26 января 1989 г., ред. Н.И. Николаев, Ленинград 1991, s. 94-97.

${ }^{5}$ P. Kennedy Grimsted, op. cit., s. 85.
} 
blikowała tekst Уникальные западноевропейское:печаные книги XV-XVI веков из трофейного собрания Российской государстенной библиотеки ${ }^{6}$.

Pisząc o rękopisach, inkunabułach i starodrukach, które przywędrowały do ZSRR, Dołgodrowa wskazała, iż w Muzeum Książki przy RBP (Музей книги РГБ) znalazły się bardzo rzadkie, a nawet unikalne ich egzemplarze. Świadczą o tym książki hiszpańskie, np. jedyny na świecie egzemplarz druku wydanego w Segowii około 1473 r. Jest to indulgencja w języku katalońskim kardynała Rodrigo de Borja, późniejszego papieża Aleksandra VI, która nawoływała do wyprawy krzyżowej przeciw Turkom. Nieznany jej typograf zyskał miano „drukarza indulgencji Borgia”. Druk ten w odróżnieniu od innych publikacji iberyjskich z Barcelony czy Walencji nie nawiązywał do form włoskich, lecz do wzorców z dolnych Niemiec ${ }^{7}$. Inna indulgencja pochodząca z około 1492 r. wydana w Valladoid jest także jedynym egzemplarzem na świecie. Jej anonimowy drukarz pracował w zakonie św. Franciszka w Prado, zyskując przydomek „drukarza Pana naszego z Prado”. Wydał on jeszcze trzy inne indulgencje, tłoczone różnymi rodzajami czcionek. Rzadkość z Hiszpanii stanowi również łaciński rękopiśmienny brewiarz z datą 1483 na ostatniej kartce, pisany literami czarnymi, czerwonymi i niebieskimi. Jego osobliwością są dodane drukowane nuty ${ }^{8}$. Bardzo wartościowym zabytkiem jest 91-kartkowy pergaminowy rękopis zawierający statut króla Kastylii i Aragonii z 1609 r., w którym znajdują się miniatury wykonane temperą ${ }^{9}$. Wśród unikatów jest wydany przez Pedro Poze w Barcelonie w przedziale lat 1499-1505 utwór Drzewo poznania autorstwa średniowiecznego filozofa i poety Ramona Lulla. Książka ta zawiera wiele miniaturowych ilustracji - jeden zachowany egzemplarz posiada RBP, drugi znajduje się w Madrycie. Także w RBP można odnaleźć egzemplarz anonimowego utworu Amadis $z$ Walii (Amadis de Gaula...), romansu rycerskiego znanego na Półwyspie Iberyjskim już od XIV w. Utwór ten wydano po raz pierwszy w Saragossie w 1508 r. W Muzeum Książki natomiast znajduje się egzemplarz opublikowany przez Jakuba Krombergera w Sewilli w 1549 r. ${ }^{10}$ Jest też tom Don Kichota Miguela de Cervante-

${ }^{6}$ О. Бородин, Пол бека в плену, „Наше Наследие” 1994, но 32; О. Бородин, Т. Долгодрова, Коллекция Немеиякого музея книги и шрифта в собрании Российской государственной библиотеки, „Наше Наследие” 1997, но 32; Т. Долгодрова: Уникальные западноевропейское:печаные книги XV-XVI веков из трофейного собрания Российской государстенной библиотеки, „Наше Наследие” 1997, но 32.

7 Eadem, Испанские книжнье редкости XV-XVI вв. хранящиеся в РГБ, [w:] Kultura, historia, książka, red. A. Dymmel, B. Rejakowa, Lublin 2012, s. 175.

8 Ibidem, s. 177.

9 Ibidem, s. 178.

${ }_{10}$ Ibidem, s. 181. Dzieło to pod tytułem Amadis de Gaula. Las Sergas del muy virtuoso y esforçado caballero Esplandium hijo de Amadis de Gaule, Sewilla 1549 występuje pod numerem 176 w kolekcji Carla Bechera. Jego tłumaczenie niemieckie wydane w Augsburgu w 1578 roku pod tytułem: 
sa wydany w Walencji przez Pedro Patricia Meya w 1605 r. Z publikacji włoskich również bardzo rzadkim dziełem są ćwiczenia duchowe (Exercitia spirytualia) Ignacego Loyoli wydane w Rzymie przez drukarza Antonia Blado w 1548 r. Książka ta nie była w sprzedaży, służąc wyłącznie ćwiczeniom duchowym jezuitów ${ }^{11}$. Wśród egzemplarzy jedynych na świecie niewystępujących w bibliografiach są Horae Antwerpia 1487, Herbarius Mainz 1484, Hortulus animae i inne, a przede wszystkim jeden z najlepiej zachowanych egzemplarzy 42 -wierszowej Biblii Jana Gutenberga ${ }^{12}$.

Tatiana Dołgodrowa słusznie zatem zauważyła, że nowe zasoby książek sprowadzone po wojnie do Muzeum Książki przy Państwowej Publicznej Bibliotece ZSRR w Moskwie stworzyły sprzyjające warunki dla dopełnienia wiedzy w Rosji o książce europejskiej czasów średniowiecza i działalności wydawniczej w okresie renesansu ${ }^{13}$. Wskazała przy tym, że badania nad inkunabułami prowadzono w Rosji jeszcze przed wojną. Kraj wówczas posiadał ich 18 tysięcy. Po dołączeniu do tego zasobu woluminów zdobycznych ich liczba wzrosła do 33 tysięcy. Połowę stanowiły inkunabuły niemieckie i niderlandzkie. 5,5 tysiąca druków przywiezionych do Moskwy w 1946 r. znajduje się w RBP. Według Dołgodrowej książki te stanowią dziś bardzo ważny materiał źródłowy dla światowych studiów inkunabulistycznych. Praca przy nich powala na otrzymywanie nowych materiałów i nawiązywanie kontaktów z uczonymi zagranicznymi. Jednocześnie rezultaty badań rosyjskich uczonych nie tylko wzbogacają rodzimą naukę, ale co ważne, przyciągają uwagę badaczy obcych ${ }^{14}$.

W ostatnich latach w Muzeum Książki przy RBP prowadzono intensywne badania naukowe nad zbiorami pochodzącymi z lipskiego Niemieckiego Muzeum Książki i Pisma (Deutsches Museum für Buch und Schrift, obecnie Deutsche Buch und Schriftmuseum) oraz drezdeńskiej Saksońskiej Biblioteki Krajowej (Sächsische Landesbibliothek). Dzięki temu pojawiła się seria wydawnicza „Коллекции Российской государственной библиотеки", w ramach której wydano trzy opracowane naukowo katalogi poświęcone książkom i drukowanym tkaninom z lipskiego muzeum oraz składający się z dwu części, jeszcze niedokończony katalog czwarty - dotyczący opraw artystycznych książek z Saksońskiej Biblioteki Krajowej. Autorem, współautorem lub redaktorem katalogów jest T. Dołgodrowa.

Amadis de Gaula. Des Anhangs zu dem Buch Splandiani, so newlich in Grechich sprach erfunden, und in die Italianisch gebracht, folgends auss derselbingen verteüstch vorden, verite aussfürsung... występuje w drugiej części katalogu Krauzego pod numerem 418.

11 Т. Долгодрова, Испанские кнжные редкости XV-XVI вв..., s. 179-180.

12 Т.А. Долгодрова, Немецзкая и Нидерландская книга XV века. (Пробемь взаимовлияния и национальные особенности), Москва 2000, s. 3-4.

${ }^{13}$ Ibidem.

${ }^{14}$ Ibidem, s. 4. 
Pierwszy z nich, wydany w Moskwie w 2007 r., nosi tytuł Каталог художественных переплетов собрания Карла Бехера (Katalog artystycznych opraw ze zbiorów Carla Bechera). Jest on ważnym źródłem wiedzy o gustach artystycznych kolekcjonerów opraw książkowych, a poniekąd również o historii książki drukowanej, czasami też rękopiśmiennej. Żyjący w Karlsbadzie w drugiej połowie XIX i pierwszej dekadzie XX w. (zm. w 1911 r.) dr medycyny C. Becher był pod koniec XIX w. osobą znaną w świecie kolekcjonerów książek. W latach 80. XIX w. nabył on od duchownego Hassaka Tetschena bibliotekę, którą znacząco wzbogacił, zwracając szczególną uwagę na artystyczne oprawy. Tak więc podstawę dla biblioteki Bechera stanowiły książki ze zbioru Tetschena. Becher oprócz artystycznych opraw książkowych interesował się herbarzami, atlasami botanicznymi i książkami krajoznawczymi, zwłaszcza poświęconymi jego rodzimemu Karlsbadowi ${ }^{15}$. W 1911 r. Deutsches Museum für Buch und Schrift zainteresowało się kolekcją opraw artystycznych książek Bechera i odtąd zaczęto w nim prowadzić badania nad artystycznymi oprawami książek. Zbiory Bechera wraz z rękopiśmiennym ich katalogiem przywędrowały do Moskwy z Lipska pod koniec 1945 r. Znalazły się w komnacie-sejfie, w specjalnych futerałach przeznaczonych dla „wojennych trofeów”. Tego typu pomieszczenie pozwoliło uchronić je przed dewastacją, w przeciwieństwie do innych sprowadzonych do ZSRR tego typu książek, pozbawionych należytego zabezpieczenia. Jednakże do czasów pierestrojki nie było nic o nich wiadomo w kraju, a także za granicą.

Według odręcznych zapisów katalogu lipskiego, w kolekcji Bechera znajdowało się 421 pozycji, w przeważającej mierze książkowych, gdyż było tam również 35 samych opraw. Dołgodrowej udało się ustalić, że nie wszystkie eksponaty figurujące w tamtym katalogu przywędrowały do Moskwy. Toteż jakkolwiek wydany przez nią drukiem katalog zawiera liczbę 421 eksponatów, to posiada przerwy w ciągłości liczbowej, nie uwzględniając 35 eksponatów odłączonych od tej kolekcji w trakcie transportu. Gdy się jednak weźmie pod uwagę klocki, nazywane też konwolutami, to liczba tytułów wzrośnie aż do 550. Tylko jedna z tych opraw, którą Dołgodrowa nazwała jezuicką, obejmująca dzieła Alojza Merza, zawiera aż 15 tytułów ${ }^{16}$. Jeżeli chodzi o oprawy w zbiorze Bechera, to posiadają je rękopisy pochodzące z XIVXVIII w. w liczbie 14, inkunabuły w liczbie 13. Pozostałe to starodruki. Trzeba również wspomnieć o 35 samych oprawach bez jakiegokolwiek tekstu ${ }^{17}$. Katalog uzupełniają 92 kolorowe ilustracje omawianych opraw. Dołgodrowa wskazała, że

15 Т.А. Долгодрова, Доктор Карл Бехер и его собрание исторически переплетов, [в:] Каталог художественных переплетов собрания Карла Бехера, Москва 2007, s. 10.

16 Ibidem, s. 107-114.

17 Ibidem, s. 23. 
przy tworzeniu katalogu współpracowała z uczonymi zagranicznymi: pracownikami Niemieckiego Muzeum Książki i Pisma w Lipsku Lotharem Pöthe i Helmą Schaefer, dr. Anthonym Hobsonem z Wielkiej Brytanii oraz Fabianem le Bar z Francji.

Tatiana Dołgodrowa przedstawiła we wstępie dzieje introligatorstwa europejskiego od średniowiecza przez czasy nowożytne, wskazując na jego ewolucję. Pisała, że oprawy piętnastowieczne charakteryzowały się prostymi dekoracjami okładek oblekanych skórą, na których znajdowały się ślepe wyciski prostokątne. Na powierzchni rombów tworzono ornament, w który wtłaczano figury heraldyczne, zwierzęce i roślinne. Często postacie umieszczone w tłokach miały znaczenie symboliczne, np. w przypadku ewangelistów. Kiście winogron znamionowały Chrystusa, a gniazda (розетки) - Dziewicę Marię ${ }^{18}$. To uległo zmianie w XVI w., kiedy pojawiły się różnorodne dekoracje. Linie odciskanego ornamentu cechowały się swobodą plastyczną, zachowując jednocześnie geometryczne prawidłowości, co stanie się regułą $\mathrm{w}$ wieku XVI i następnych. Niekiedy na oprawy nanoszono pergaminowe bądź papierowe kartki z tytułami książek, względnie z nazwiskiem autora ${ }^{19}$.

W celu lepszego zrozumienia podawanych w skondensowanej formie opisów opraw Dołgodrowa we wstępie do katalogu przedstawiła funkcjonowanie introligatorstwa na przestrzeni wieków nie tylko w Europie, lecz także w krajach islamskich, a nawet w Chinach. Wskazała, iż w średniowieczu do opraw książkowych używano nieograniczonej ilości materiałów, jak drewno czy tektura, a do okładania opraw: skóry, jedwabiu, aksamitu, sznurów pereł i koralików, kości słoniowej, drogocennych kamieni, zaś dla uzyskania koloru szlachetnych metali: złota, srebra i platyny oraz różnokolorowych emalii. Dzięki temu oprawy książkowe stanowiły dzieło sztuki jubilerskiej. Ich forma niekiedy przypominała trójwymiarową rzeźbę ${ }^{20}$.

Jak wskazała autorka, za sprawą udoskonalonych dekoracji w XVI w. zniknęła surowa prostota opraw książkowych. Ślepe wyciski, przybierając cienkie delikatne kształty, stały się wykwintnymi. W ślad za tym zaczęły się pojawiać elementy dekoracyjne $\mathrm{w}$ rozdrobnionych formach. Na oprawach zaczęły dominować złote wyciski, które zapoczątkowano we Florencji w XV w. Najstarszy egzemplarz takiej oprawy jest przechowywany obecnie w Oxfordzie. Jedna z takich opraw znajduje się w kolekcji Bechera pod numerem 368, którą zawiera włoski rękopis Diktysa z Krety zatytułowany De bello Troiano, ad de reditu Graecorum. Dając komentarz do tego typu opraw, Dołgodrowa przychyliła się do opinii badacza niemieckiego F.

\footnotetext{
18 Ibidem, s. 12-13.

19 Ibidem, s. 13.

20 Ibidem, s. 10.
} 
Sarre, który w pracy Islamische Bucheinbände, wydanej w Berlinie w 1923 r. twierdził, że ten sposób wycisków był rozpowszechniony w świecie arabskim już w XIV w. ${ }^{21}$

Katalog dowodzi znawstwa historii sztuki i bibliologii u Dołgodrowej. Opisy na każdej stronie występują w dwu kolumnach. Pierwsza z lewej strony zawiera dane bibliograficzne dzieła, którego opisów dokonano w oparciu o Bibliograficzieskij zapis Rosji z 2004 r. W pierwszej kolejności wymienia się nazwiska autorów, podając w nawiasie daty ich życia, po tym tytuły książek w językach oryginału (łacina, francuski, niemiecki, włoski, angielski, hiszpański i rosyjski), dokonując - dowolnego jak się zdaje - tłumaczenia tytułu na język rosyjski, następnie miejsce i rok wydania. Ponadto $w$ wielu wypadkach wymienia się oficyny wydawnicze, nazwiska nakładców wraz z odesłaniem do odpowiednich kompendiów biograficznych i bibliograficznych, np.: Allgemeine deutsche Biographie... Bd. 1-56, Leipzig 1875-1915; J. Baudrier: Bibliographie Lyonnaise, t. 1, Lyon 1897; J. Benzing: Die Buchdrucker des 15. und 17. Jahrhunderts im deutschen Sprachtgebeit, Wiesbaden 1963; Catalogue of books printed in the XVth Century, Now in the British Museum, London 1908-1971; K. Estreicher: Bibliografia polska; XV-XVIII Stolecie; J.C.T. Grease: Tresor des livres rares et précieux..., Dresden 1959-1867, t. 1-7 i inne ${ }^{22}$.

Autorka informuje o formacie książek, liczbie stron, ilustracjach, kolorze, względnie kolorach liter w tekście, a także na karcie tytułowej. Jeśli karty tytułowe posiadają portrety autorów książek, również o tym wspomina. Poza techniczną stroną druku Dołgodrowa ukazała ręczne dopiski na kartach tytułowych oraz forzacach. Wymieniła ekslibrisy i superekslibrisy oraz odciski pieczęci, będące świadectwem przynależności książek do różnych właścicieli bądź kolekcji bibliotecznych. Mówiąc o ekslibrisach, trzeba zaznaczyć, że wskazała je również w następnej kolumnie, ale tylko te, które wkomponowali do swych opraw artyści, a także w postaci naklejek późniejsi właściciele, zwłaszcza Becher. Dopiski na kartach tytułowych i forzacach wskazują na historię przedstawianych egzemplarzy. Zyskujemy więc informacje o zmieniających się właścicielach książek, a niekiedy też o datach ich nabywania. Znajdujemy także dedykacje dla obdarowywanych osób. Wśród tego typu zapisów jest jeden szczególny przypadek. Otóż na wydanym w Wenecji w 1538 r. włoskojęzycznym egzemplarzu dzieł Petrarki spotykamy angielskojęzyczny ołówkowy zapis właściciela, że cena tej książki w 1859 r. wynosiła pięć funtów.

W tej znaczącej kolekcji Bechera znajdują się unikatowe egzemplarze. Wymienimy tu trzy rękopisy. Jeden $\mathrm{z}$ nich stanowi książka kucharska napisana w języku angielskim w XVII w. pod tytułem Cookery-book. Z kolei rękopis dzieła Diktysa

${ }^{21}$ Ibidem, s. 13.

22 A. Krawczyk, Ksiązki z oprawami artystycznymi z kolekcji Carla Bechera w Państwowej Bibliotece Rosji, [w:] Z książka przez życie, red. A. Krawczyk, Lublin 2008, s. 193-194, przypis 10. 
z Krety, sporządzony we Włoszech w 1499 r. zasługuje na uwagę ze względu na walory artystyczne oprawy. Ona jako jedna z pierwszych i nielicznych w zachodniej Europie posiada drobne złote wyciski. Również trzeci angielskojęzyczny rękopis jest unikatowy ze względu na to, że był sporządzony na Półwyspie Indyjskim, w mieście portowym Suret, będącym pierwszą faktorią brytyjską na tym subkontynencie, około 1630 r. Jego tytuł Dictionary of English explained in Persian, Hindustani and Portuguese wskazuje, iż słownik ten miał służyć Brytyjczykom do kontaktowania się z ludnością perską, hinduską, a także Portugalczykami, również posiadającymi faktorie na tym subkontynencie.

Natomiast druga kolumna strony zawiera opis opraw. W nim autorka w pierwszej kolejności podała w milimetrach długość, szerokość i grubość książki, po tym grubość oprawy, materiał, z którego ją wykonano, następnie materiał ją przykrywający, dekoracje okładek i brzegów książek, napisy umieszczone na okładkach, pieczęcie, ekslibrisy i superekslibrisy. Ponadto określiła stan fizyczny oprawy jako bardzo dobry, czy też słaby. Spisała częściowe ubytki spowodowane restauracją oprawy, a także ślady ingerencji robactwa. Tak samo będzie przy opisach opraw innych kolekcji. Dołgodrowa rozwikłała, w jakim stylu wykonano oprawę, wskazując na konkretne osoby ${ }^{23}$. W jednym ze sporządzonych indeksów dokonała zestawienia 11 mistrzów bądź też stylów przypisywanych tym mistrzom. Byli to: Derôme mł., Eve Clovis, Eve Nicolas, „Le Gascon”, „Groelier”, Lemonnier, Thomas Mathieu, Samuel Mearne, Caspar Kraft, Jacob Krause, Padeloup le Jeune ${ }^{24}$.

Na podstawie nazwisk bądź inicjałów introligatorów na oprawach książek Dołgodrowa wymieniła 24 artystów żyjących w różnych czasach. Byli to: 1. Gregor Bemütz, niemiecki introligator z połowy XVI w., który wykonał jedną oprawę, podpisując imieniem i nazwiskiem; 2. Paulus Bernardus z Norymbergii, wykonawca jednej oprawy; 3. Jacob Bing, zamieszczający na oprawie inicjały J.B., wykonawca dwu opraw z XVI w.; 4. Heinrich Buchholtz, wykonawca jednej oprawy w XIX w.; 5. David La Mouche z Lyonu, wykonawca jednej oprawy; 6. Derôme mł. z Francji z XVIII w., wykonawca jednej oprawy; 7. Pierre-Paul Dubuisson z Francji XVIII w., wykonawca dwu opraw; 8. Giotto Gabrielle de Ferraris, Włoch z XVI w., wykonawca jednej oprawy; 9. Garrett Godfrey z Cambridge, działający w latach 1521-1539, wykonawca jednej oprawy; 10. Gregor Kersten z Wittenbergi, wykonawca jednej oprawy w 1560 r.; 11. Caspar Krafft z Wittenbergi, wykonawca jednej oprawy z 1562 r.; 12. Nicolaus ab Ebelsen, wykonawca jednej oprawy w Paryżu, w 1541 r.; 13. Johann der Beständige, wykonawca jednej oprawy w Wittenberdze w XVI w.; 14. Julian Notary, wykonawca jednej oprawy w Anglii w XVI w., podający swój monogram JN;

23 Т.А. Долгодрова, Каталог художественных..., s. 383-384.

24 Ibidem, s. 386. 
15. John Reynes, posługujący się monogramem JR, wykonawca jednej oprawy w Anglii w II połowie XVI w.; 16 . Thomas Krüger, wykonawca jednej oprawy w Wittenberdze w 1565 r.; 17. Joachim Kutsenteuter, wykonawca jednej oprawy w Saksonii w 1635 r., jak podkreśliła Dołgodrowa w stylu Jakuba Krauzego; 18. Lemonnier, wykonawca jednej oprawy we Francji w II połowie XVIII w.; 19. Charles Mearne, wykonawca trzech opraw w Anglii w II połowie XVII w.; 20. Samuel Mearne, twórca pięciu opraw w Anglii w II połowie XVII w.; 21. Powołując się na monogram artysty BM, Dołgodrowa poczyniła domniemania, że twórcą oprawy wykonanej w połowie XVI w. w Dreźnie bądź Torgau mógł być Balthasar Metzner z Drezna albo Barthel z Torgau; 22. Johann Noris, twórca jednej oprawy flamandzkiej z II ćwierci XVI w.; 23. J. Thouvenin, twórca jednej oprawy wykonanej we Francji, z pierwszej połowy XIX w.; 24. C.W. Wogt, twórca jednej oprawy wykonanej w Berlinie w I połowie XIX w. ${ }^{25}$

Autorka zwróciła też uwagę na oprawy stylizowane wykonywane na wzór dawnych mistrzów. Do takich zaliczyła oprawę wykonaną do wydanego w Turynie w 1833 r. Almanacco Pienmontese, Il Palmaverde, sporządzoną w stylu renesansowym; oprawę do dzieła Owidiusza Heroidum epistolae, wydanego w Wenecji przez Alda Manuzia w 1502 r., którą wykonano w Wenecji w XVII w., imitującą oprawy z pracowni Alda Manuzia; oprawę do Amadis de Gaula... wydanego w Sewilli w 1549 r., wykonaną w Wenecji w XVII w. w stylu imitującym hiszpańsko-mauretańskie oprawy z XVI w. oraz oprawę do Etymologiae Izydora, wydanych w Augsburgu, w 1477 r., wykonaną w Niemczech w drugiej połowie XVI w. na wzór opraw piętnastowiecznych ${ }^{26}$.

W podsumowaniu prezentacji przedstawionych przez siebie opraw Dołgodrowa na stronach 386-387 w jednym z indeksów wskazała na 15 stylów, w jakich introligatorzy upiększali swe oprawy, tworząc je w przedziałach występujących na gruncie historii sztuki epok: gotyku, renesansu i rokoka, opisując je w ujęciu alfabetycznym. Ich charakterystyka zostanie tu przedstawiona.

1. Styl owalny (all-over style). Charakteryzował się on wyciskami owalnych syluetów albo ich części posiadających kształty podobne do jajek. Stosował go angielski introligator Samuel Mearne, sporządzając oprawy do dwu egzemplarzy Ladies Calling, wydanych w typografii teatru oxfordzkiego w 1676 r. Także w tym stylu wykonał oprawę do dzieła The Government of the Tongue (Oxford 1667). Dołgodrowa ponadto $\mathrm{w}$ różnych miejscach przedstawiła go jako wykonawcę innych opraw w różnych stylach. Również wskazała na oprawy wykonane w różnych stylach przez adeptów jego szkoły, wśród których wymieniła jego syna Charlesa.

25 A. Krawczyk, Książki z oprawami..., s. 201, przypis 28.

${ }_{26}^{26}$ Ibidem, s. 202; Т.А. Долгодрова, Каталог художественных..., s. 161-162, 186-187, 188, 244-45. 
2. Styl katedralny albo gotycki, nazywany również pseudogotyckim (cathedrale style). Jego oprawy posiadały obiekty wyciskane na kształt katedry. Na kolorowej skórze wyciskano kontury ze złota, barwiąc je farbami olejnymi koloru czerwonego, zielonego, szarego i żółtego. Boki książki były pozłacane. Przykładem tego jest oprawa wydanego w 1828 r. w Paryżu i Lyonie Breviarium Romanum wykonana we Francji w I połowie XIX w. Inna oprawa do wydanego w Darmstadt w $1838 \mathrm{r}$. Allgemeines Evangelisches Gesangbuch für das Grossherzoherzoktum Hessem, wykonana przez mistrza niemieckiego mającego monogram LG w $1838 \mathrm{r}$. Jeszcze inna do dzieła Gerardi Croessi historia quakeriana..., Amstelodami 1695 wykonana przez mistrza francuskiego w I połowie XIX w. oraz oprawa do Novenne per le principali feste dell' anno, Firenze 1833, wykonana przez włoskiego mistrza w poł XIX w.

3. Styl rustykalny (cottage style). Cechował się tym, że na okładkach wyciskano sylwetkę domu. Wiąże się on również z osobą angielskiego introligatora Samuela Mearne’a. Jako przykład można podać The Ladies calling in two part, Oxford 1675, w którym w środku okładki wytłoczony jest obiekt w kształcie domu, i dzieło Thomasa Berneta: A short introduction of grammar..., wydane w Londynie w $1680 \mathrm{r}$., a także oprawę do dzieła Johna Dennisa: The Battle of Ramilla..., London 1706. O tej oprawie pisała Dołgodrowa, iż jej mistrz nawiązywał do szkoły Samuela Mearne’a. Tak samo stwierdziła o oprawie książki zatytułowanej Mary Chudleigh: Essays upon several subjects in prose and verse, London 1710, wskazując, że naśladuje ona styl Samuela Mearne’a.

4. Styl koronkowy (la dentelle) został przejęty do opraw książkowych ze sztuki jubilerskiej. Polegał on na ząbkowanym tłoczeniu koronek. Był charakterystyczny dla francuskich mistrzów Jeana Antoine’a Derôme’a (zm. 1760) i jego syna Nicolasa Denisa. Stosownie do kanonów tego stylu pod koniec XVII i przez wiek następny zaczęto stosować na bordiurach tzw. koronkowy wycisk. Dla dekoracji wykonywano kontury ptaszków (dentelle avec les oiseaux). Przykładem tego może być oprawa książki religijnej Marii Leszczyńskiej: Euculoge livre d'eglise, qui continent l’office du matin et du soir, pour les dimanches et les fetes de lanée, Paris 1761, wykonana przez Lenonniera. W jej centrum znajduje się ekslibris królowej. Ramka posiada linie i drobne kółka. Na okładce występują małe wyciski na kształt kwiatów i gałęzi. Podobną oprawę ma książka Heweliusza: Johannis Hevelli. Descriptio cometae anno.. MDCLIV ..., Gedani 1666, wykonana przez włoskiego mistrza w XVII w. Oprócz tego stylu na oprawie występują elementy stylu wahadłowego, przy pomocy którego wykonano ornament.

5. Styl rysunkowy albo kreślarski (drawer handle) posiadał charakterystyczne półokręgi z wolutami. W Anglii stosował go Charles Mearne. Wykonał on oprawę do dzieła Josepha Alleine'a: A most familiar explanation of the Assamblies shorter Catechism..., London 1764. Na okładkach pokrytych jedwabiem są wytłoczone linie 
i ornamenty gałązek oraz kwiatów. Ten sam introligator wykonał oprawę dla The Book of prayer and administration of the sacrament and other rites and ceremonies of the church..., Cambridge 1675. Na okładkach pokrytych ciemnobrązową skórą znalazły się wyciski złotych linii.

6. Styl plecionkowy (enterlacs) autorka pokazała na jednym przykładzie, eksponując oprawę wykonaną w Lyonie w 1549 r. do książki M.T. Ciceronis Epistolae ad Atticum, Brutum et Q. Fratrem, Lyon 1546. Na brązowej cielęcej skórze oprawy, mającej złoty zanikający wycisk z ubarwieniem farbami olejnymi czarnego i białego koloru, jest dekoracja z materiałów plecionkowych i wstążkowych.

7. Styl wachlarzowy (à l'éventail) stanowił dekoracje okładek na podobieństwo wachlarza. Forma ta pojawiła się w Hiszpanii w XVII w., a następnie w innych krajach Europy. Dołgodrowa, eksponując oprawę książki Jeana Claude’a de la Corvée: De nuratione foetus in utero paradoxa, Danzing 1655, pisała, że na okładce od wewnątrz narożników, a także w jej środku znajdują się wachlarze. Oprawę tę wykonano we Francji w połowie XVII w. Podobnie rzecz się ma przy oprawie książki Anselma Desinga: Index poeticus..., Ingolstadt, Augsburg 1747. Oprawa tej książki, mająca od strony wewnętrznej wachlarze, powstała w Austrii w $1747 \mathrm{r}$.

8. Styl fanfarowy (à la fanfare) cechował się tłoczeniem na oprawie drobnych złotych elementów przy pomocy drobnego stempla. Początki tego stylu sięgają XVII w., ale jego nazwa przyjęła się w XIX w. Widoczny jest on na oprawie rękopisu dla króla Henryka III: De chrismandis in fronte..., wykonanej przez Eve Clovisa w XVI w. oraz oprawie książki Anthony’ego Hornecka: The crucified Jesus..., London 1700, wykonanej przez Charlesa Mearne’a. Na skórze czarnego safianu znajduje się wytłoczony barwny ornament i inkrustacja.

9. Dla stylu kwiatowego stokrotkowego (à la marguerite) autorka podała zaledwie jeden przykład oprawy, jaką posiada Biblia V.T. Psalterium Lat., wydana w Paryżu w 1588 r. Stwierdziła ona zdawkowo, że na okładce obłożonej skórą marokańską (safianem) jest złoty wycisk w stylu Mikołaja Eve’a, nazywany stokrotkowym.

10. Styl geometryczny (rectangular style) sprowadzający się do tłoczenia kwadratów i wielokątów występuje w oprawach Samuela Mearne’a i innych introligatorów. Egzemplifikuje go oprawa książki Thomasa Adamsa: The main principles of Christian religion in an 107 short articles or aphorisms..., London 1675, wykonana w II połowie XVII w. przez mistrza Samuela Mearne’a. Na okładce pokrytej czarnym safianem zawarto złoty wycisk i malowidła wykonane szarą farbą olejną w formie figur geometrycznych. Również oprawa książki domniemanego autorstwa lady Pakington bądź arcybiskupa Sterne’a: The Ladies calling..., Oxford 1676 została wykonana przez tego samego mistrza. Na pokryciu okładek czarnym safianem wytłoczono złote figury geometryczne. W tym stylu jest także oprawa nieznanego siedemnastowiecznego angielskiego mistrza do książki The art of contentment by the author of the Whole 
Duty of Man..., Oxford 1677. Okładki książki zostały pokryte czerwonym safianem $\mathrm{z}$ tłoczonymi złotymi figurami w stylu geometrycznym.

11. Styl symboliczny (fers symboliques), jak wskazuje nazwa, charakteryzuje się występującymi symbolami. Można go podziwiać w oprawie wykonanej w $1818 \mathrm{r}$. przez mistrza niemieckiego mającego monogram MEH do książki Neues Hirschbergisches Gesangbuch, elches aus 1500 alten und neuen geistreichen lieden bestelt, Hirsberg 1797. Na okładce występują dekoracje wstążkowych ornamentów z niemalowanego pergaminu i wyciski w kształcie rogu obfitości, korony gałęzi, róż, a w środku kartusz ze złotego tłoczenia wyobrażający Baranka Bożego w obramowaniu gałęzi z kwiatami. Inna oprawa śpiewnika Allgemeines Gesangbuch..., Altona z 1786 r. wykonana w 1798 r. przez niemieckiego introligatora o autografie J.M.G.S. zawiera na pergaminowym obiciu wytłoczone ornamenty z symbolami. Jeszcze inna, tzw. oprawa wieśniacza, śpiewnika Allgemeines Gesangbuch, nebst einem Anhang von Gebeten und Texte, worüber gepredikt wird, auf Könglichen Allergnädicsten Befhel, Kiel 1797 zawiera złote wyciski emblematów urn oraz narzędzi pracy ludzkiej, które mogą być symbolami śmierci. Tego typu oprawy pochodzą również z Anglii. Posiada je książka Ride’s British Merlin for year, Londyn 1770. Na obiciu oprócz stylu rustykalnego jest również symboliczny ornament $\mathrm{z}$ kwiatami, koroną i rogiem obfitości.

12. Styl empire Dołgorowa ukazała tylko na jednej oprawie pozbawionej dzieła. $\mathrm{Z}$ zapisu dowiadujemy się, że sporządzona została przez angielskiego introligatora na początku XIX w. Okładki oprawy obłożone czarnym safianem posiadają ślepy złoty wycisk i inkrustację z barwnej skóry w kolorach czerwonym, zielonym i fioletowym. Elementy zdobnicze występują w formie stylizowanych lotosów i kulek. Fon rozbity na cztery prostokąty zawiera wpisane w nie romby.

13. Wskazując na styl klasyczny, autorka pisała, iż wniósł on do opraw wykonywanych w wiekach XVII i XVIII uporządkowaną i geometryczną wyrazistość proporcji i detali. W dekoracjach pojawiły się fragmenty przedstawiające antyczną architekturę i rzeźbę, popiersia, profilowane portrety, kolumny, frontony i wazy. W katalogu przedstawiono trzy eksponaty. Pierwszy z nich to oprawa książki Emanuele Tesauro Il cannocchiale Aristotelico, osia. Idéa del arguta et ingeniosa elocutione, che serus à tutta l'arte oratoria..., Roma 1664. Oprawa wykonana w Italii w XVII w. posiada okładki pokryte czerwonym safianem ze złotym wyciskiem w stylu klasycznym. Styl ten reprezentuje również oprawa innej książki Henrici Cannegieteri Dissertatio de Britenburgo, matribus, britiss, britannica herba..., Hague 1734, wykonana w Niemczech w XVIII w. Środek okładki zawiera elementy klasycystyczne. Wreszcie w książce Johanna Henricha Wilhelma Witschela Morgen und Abendopfer in Gesangen... Neueste verbesserte und vermehrte Ausgabe, Wien 1810 na okładce znajduje się medalion z inkrustacją ciemnozielonej skóry, od której odchodzą promienie w stylu klasycystycznym. 
14. Przedstawiając styl rokoko, autorka wskazała na wykonaną w Wiedniu w II połowie XVIII w. oprawę dzieła medycznego Antonii de Haen... Rationis modendi in nosocomio practico, Wien 1765-1768. Okładki są obłożone czerwonym safianem ze złotym wyciskiem w tym stylu. W stylu rokoko jest także modlitewnik wykonany w Italii w II połowie XVII w., zatytułowany Uffizio dei defonti secondo la volgata glossa Latina parafrasi Italiana..., Siena 1781. Okładki pokryte czerwonym safianem mają charakterystyczne złote tłoczenie. Również w tej kolekcji znajduje się oprawa wykonana w tym stylu do almanachu pod tytułem Etrennes mignones, curieusies, utiles, et interesantes... Pour l’an IX-e de la République Française, Paris 1800, wydanego z okazji dziewiątej rocznicy republiki. Styl ten znamionuje dekoracja okładki.

15. O stylu tulipanowym Dołgodrowa pisała, że pojawił się w Europie w XVI w. po sprowadzeniu na kontynent tych kwiatów $\mathrm{z}$ Turcji. W wieku tym zaczęto wykonywać stemple do opraw w kształcie tulipanów. Spotkać się z tym można w oprawie Samuela Mearne’a do łacińskiej Biblii Starego i Nowego Testamentu wydanej w Londynie w 1661 r., w której obok dekoracji w różnych stylach znalazły się tulipany. Tenże artysta na innej wykonanej przez siebie oprawie w stylu geometrycznym do dzieła The Art of Contentment zamieścił także wycisk tulipanów. W Niemczech widzimy wyciski tulipanowe wykonane w XVII w. na oprawie do dzieła Jacoba Masena Anima historiae huius temporis is in juncto Caroli V et Ferdinandi I fratrum imperio..., Coloniae 1671. Także inny mistrz, mający monogram MER, na wykonanej oprawie modlitewnika wydanego w Hamburgu w 1795 r. posłużył się tym stylem. Natomiast we Francji zostały wykonane przez Padeloupa młodszego lub Lemonniera ozdoby opraw w stylu tulipanowym z II połowy XVIII w. do modlitewnika dla kobiet Etrennes spiritualles dédiées aux Dames, contenant l'Office Latin et Francois, suivant le Nouveau Bréviaire et Missel de Paris et de Rome, Paryż 1778-177927.

Już tylko na podstawie nielicznych podanych wyżej przykładów egzemplifikujących stosowanie różnych stylów opraw można było zauważyć, że nie wszyscy introligatorzy wykonywali oprawy wyłącznie w jednym stylu. Świadczą o tym choćby oprawy wykonywane przez mistrza Samuela Mearne’a i adeptów jego szkoły. Głębsze studia przedstawionych opisów pozwoliłyby wysnuć udokumentowany wniosek, że wiele opraw książkowych z kolekcji Bechera posiadało eklektyczny charakter. Bardzo cennym przewodnikiem do głębszych studiów są różnego rodzaju indeksy dotyczące samych opraw, materiałów używanych do opraw książek, stylów opraw, monogramy mistrzów wykonujących oprawy oraz krajów, w których wykonywano oprawy. Dołgodrowa wymieniła 12 takich krajów. Najwięcej wykonano ich w Niemczech, bo aż 114 (choć dwie z nich mogą nie należeć do kolekcji Beche-

27 A. Krawczyk, Książki z oprawami..., s. 196-200. Podane wyżej informacje dotyczące poszczególnych stylów pochodzą z wymienionego w niniejszym przypisie mojego opracowania. 
ra). W dalszej kolejności we Włoszech 111, we Francji 97, w Anglii 40, Flandrii 8, Hiszpanii 5, Szkocji 4, Turcji 4, Austrii 5, Rosji 2 i 1 w Mauretaniii ${ }^{28}$. Również cenne są wykazy ekslibrisów, superekslibrisów, pieczęci bibliotek, do których należały książki. To stwarza podstawy do studiów księgoznawczych oraz dotyczących kolekcjonerstwa książek. Z braku miejsca pominięto $\mathrm{w}$ tych rozważaniach tytuły książek występujących w kolekcji Bechera, a jest to bogata paleta tytułów od dzieł literackich, historycznych, religijnych różnych wyznań, filozoficznych, medycznych po prognostyki i kalendarze.

Na dawnych właścicieli książek wskazuje 55 superekslibrisów; wśród nich papieży: Klemensów X i XI, Benedykta XIV i Piusa IV, cesarza Józefa II, królów Francji: Henryka III, Ludwika XV, królowe Marię Leszczyńską i Marię Antoninę, Fryderyka króla Danii, władców z dynastii Medicich i Tudorów, Karola II Stuarta, króla Prus Fryderyka II Wielkiego, elektora saskiego Augusta, elektorów burgundzkiego i wittenberskiego i wielu pomniejszych osób ${ }^{29}$.

W podobny sposób skonstruowano inny katalog - Каталог набивных тканей собрания Роберта Форрера (Katalog wzorzystych tkanin ze zbiorów Roberta Forrera). Poświęcono go tkaninom, na których wiele wieków wcześniej od książek wyciskano wzory. Kolekcję tę, podobnie jak w przypadku kolekcji Bechera sprowadzono do Muzeum Książki w ZSRR w 1946 r. Na początku sporządzonego katalogu Dołgodrowa umieściła wprowadzenie na temat zawartości, po czym przystąpiła do przedstawienia trzech grup eksponatów według rozmiarów tłoczonych na nich wzorów. Wydzieliła trzy grupy eksponatów oznaczonych literami alfabetu łacińskiego A, B i C. Grupa A, wyodrębniająca najmniejsze rozmiary wzorów, zawiera opis 80 tego typu eksponatów z 6 ilustracjami. Grupa B zawiera opis 86 eksponatów średniej wielkości, które zobrazowano na 51 ilustracjach, zaś grupa $\mathrm{C}$ z największymi rozmiarami ilustracjami zawiera 7 opisów eksponatów z 4 ilustracjami. Tekst opisu występuje w języku rosyjskim. Jakkolwiek ilustracje, choć zamieszczone, można powiedzieć, w sposób przypadkowy na różnych stronach katalogu, nie zawsze korespondujące z opisywanymi eksponatami, to trzeba wskazać na bardzo artystyczne ich wykonanie. Przyciągają one uwagę obserwatora. Katalog ten Dołgodrowa sporządziła przy konsultacji z uczonymi zagranicznymi i krajowymi, m.in. Lotharem Pöthe z Niemieckiego Muzeum Książki i Pisma w Lipsku, Rozą Aleksandrowną Bagnik z RBP, a także paryskimi instytucjami: Dom Nauk o człowieku (Maison des sciences de l'home), Muzeum Drukowanych Tkanin i Muzeum Sztuki dekoracyjnej w Paryżu³ ${ }^{30}$.

28 Т.А. Долгирова, Каталог художественных..., s. 393-394.

29 Eadem, Доктор Карл Бехер..., s. 20.

${ }^{30}$ Eadem, О собрании набивных тканей XIII-XIX веков Роберта Форрера, [в:] Каталог набивных тканей ХІІІ-ХІХ веков собрания Роберта Форрера, Москва 2010, s. 29. 
Tatiana Dołgodrowa uważała R. Forrera (1866-1947) za twórcę podwalin do nowej dyscypliny naukowej, tj. studia nad zadrukowanymi tkaninami (zeugdrucke), z powodu występujących na nich ilustracji oraz pisma. Eksponuje wydaną przezeń w Strasburgu w 1894 r. fundamentalną monografię Die Zeugendrucke der byzantinischen, romanischen, gotischen und späteren Kunstepochen (Druk na tkaninach bizantyńskich, gotyckich i późniejszych epok), w której analizie poddał 129 fragmentów różnych ozdobnych tkanin, poczynając od VI w. W 1898 r. w Strasburgu wyszła druga równie ważna jego monografia Die Kunst des Zugdrucke vom Mittelalter bis zur Empirezeit (Sztuka druku na tkaninach od średniowiecza do czasów imperium francuskiego), w której przedstawił historię wykorzystania znaków niezbędnych do ilustracji książek dla zdobienia tkanin w różnych państwach europejskich, w tym także Rosji. Z innych prac warto zwrócić uwagę na: Geschichte des Gold - und Silberschmuckes nach Originalen der Strassburger nach Originalen der Strassburger historischen Schmusk - Ausstelung vom 1904, Strassburg 1905 i Römischse und byzantinische Seiden - Textillen aus dem Gräberfelde von Achmin - Panopolis..., Strassburg $1891^{31}$.

Autorka zaakceptowała pogląd Forrera, że wykorzystywanie grawiur do zdobienia tkanin wystąpiło wiele wieków wcześniej przed drukiem książek. Posługując się pojęciem „prymitywny druk”, stwierdziła, że miał on już miejsce w czasach prehistorycznych. Na rzecz tego przytoczyła nawiązanie Forrera do Pliniusza Starszego, który w Historii naturalnej pisał o druku woskowym w Rzymie. On również wspominał o jeszcze wcześniejszym sposobie barwienia tkanin w Egipcie. Szukając innych tego typu przypadków w czasach prehistorycznych, autorka zaznaczyła, że z podobną techniką wykonywania pisanek można było się spotkać w Indiach i na Jawie. Wyeksponowała stanowisko Forrera zawarte w jego książce Die Zeugendrucke der byzantinischen, romanischen, gotischen und späteren Kunstepochen, w której wskazał, że chusty drukowane u Koptów w Górnym Egipcie na tle błękitnym, a rzadziej czerwonym wykonywano w ten sposób, jaki ukazał Pliniusz Starszy w 35. rozdziale swojej Historii naturalnej. Charakterystyczną cechą tego „druku” jest długowieczność. Świadectwem tego są zachowane do dziś eksponaty z Górnego Egiptu i od Koptów. Najstarsze obiekty to: wydobyta z dziecięcego grobu tunika pochodząca z IV w. n.e. z Panapolis oraz w Europie nadruk na tkaninie pochodzącej z VI w. n.e. z grobowca św. Cezarego, biskupa Arles. Podobną technikę barwienia jak przy wymienionych eksponatach można było spotkać w Europie w XVII i XVIII w. Barwienia tkanin dokonywano przy pomocy wosku, by w naznaczonych przy jego

31 A. Krawczyk, Katalog nabiwnych tkanij XIII-XIX viekow sobranija Roberta Forrera, Moskwa 2010, „Res Historica” 2012, nr 33, s. 266-267. 
pomocy miejscach nadać tkaninie wyrazistość rysunku. Do tego zjawiska Forrer użył określenia apprêt (wykończenie).

Tatiana Dołgodrowa przeanalizowała podane w katalogu modele ilustracji tłoczone na tkaninach na wzór książek, a niekiedy haftowane. Wykorzystując niemiecki rękopiśmienny katalog zbiorów, skorygowała zauważone w nim nieścisłości. Przeprowadziła analizę semiotyczną napotykanych znaków w eksponatach. Uzasadniła sens umieszczenia tych tkanin w muzeum książki tym, że znacznie później na książkach aniżeli na tkaninach wyciskano wzory ręcznie. Do produkcji książek i tkanin używano podobnych matryc, toteż technika produkcji książek oraz wzorzystych tkanin była powiązana z rytownictwem. Podzieliła stanowisko Forrera, że prymitywny druk na tkaninach występował już w czasach prehistorycznych - w Egipcie, Rzymie, Indiach i na Jawie. Postawiła tezę, że drzeworytnictwo rozwinęło się najpierw w miastach europejskich, w których produkowano tkaniny, a w ślad za tym zaczęto wykorzystywać je do produkcji książek ${ }^{32}$.

Autorka wskazała na style, w jakich zostały wykonane badane przez nią eksponaty. Wymieniła style: wczesnoromański, wczesnogotycki, styl Ludwika XVI, styl wschodni („oriental”), styl biedermeier, empire, w tym empire z czasów króla Ludwika Filipa I, klasycyzm, eklektyzm oraz sinizm (chińszczyzna). Zwróciła uwagę na eksponowany przez Forera dawny podręcznik dotyczący ilustrowania tkanin - średniowieczny traktat włoskiego artysty Cennino Cenniniego, napisany około 1370 r., a wydany w Moskwie w 1933 r. pod tytułem Книга об искусстве, или Трактат о живописи, a także rękopis z klasztoru św. Katarzyny w Norymberdze z przełomu XV-XVI w., będący traktatem na temat wykonywania napisów na tkaninach złotymi i srebrnymi barwami. Rękopis ten Forrer opublikował w swojej pracy Die Kunst des Zugdrucke... Dołgodrowa podała też wykaz literatury światowej oraz rosyjskiej poświęconej temu zagadnieniu.

Autorka snuje wywody na temat obustronnego oddziaływania w średniowieczu zakładów produkujących tkaniny na ilustrację książek i odwrotnie - w czasach późniejszych ilustracji książkowych na ilustrowanie tkanin. Wskazała, że matecznikiem grawerstwa książek były miejscowości, w których w średniowieczu produkowano tkaniny. Wymieniła w tym przypadku klasztor św. Katarzyny w Norymberdze, późniejszy ośrodek drukarstwa, w którym w XIII w. produkowano grawerowane tkaniny, i niderlandzkie miasto Lowanium. Następnie podała, że od XVII w. inspiracji do przedstawiania wzorów na tkaninach dostarczały ilustracje $\mathrm{z}$ inkunabułów. $\mathrm{Na}$ rzecz tego przytoczyła wykorzystywanie wzorów roślin przedstawianych w piętnastowiecznym Hortus sanitatis ${ }^{33}$.

${ }^{32}$ Ibidem, s. 268-270.

33 Т.А. Долгодрова, О собрании набивных..., s. 16. 
Tatiana Dołgodrowa poddała analizie eksponaty produkowane w Anglii, we Francji oraz Niemczech, ukazujące działalność Napoleona, a więc jego pobyt przy grobie Fryderyka II, pożar Moskwy, wkraczanie Napoleona do Moskwy, kaźń ostatniego członka z rodu Burbonów - księcia d’Enghien, pojmanie haitańskiego patrioty Toussaint L'Ouverture, zdradę przez wodza żołnierzy francuskich w Egipcie, rozstrzeliwanie jeńców tureckich, pozbawienie papieża władzy świeckiej czy też sceny z życia prywatnego Napoleona - zdobycie Józefiny, dawnej kochanki Barrasa. W odniesieniu do napisów na rysunkach przedstawiających krajobraz moskiewski autorka sprostowała podawane nieścisłości.

Katalog uzupełniają dodatki zwierające przypisy wraz z komentarzami, słownik używanych terminów, wykaz materiałów do wykonywania tkanin, rodzaje technik odciskania wzorów, indeksy nazwisk osób występujących na tkaninach, twórców wzorzystych tkanin, płócien zwierających nazwiska artystów, nazwisk posiadaczy eksponatów, tkanin przeznaczonych do celów religijnych, tkanin z tekstem, tkanin z naszywkami, tkanin wykonanych w przedziałach czasowych od XIII do XIX w., krajów, w których powstały wzorzyste tkaniny (Niemcy, Francja, Szwajcaria, Anglia, Holandia, Belgia, Włochy, Japonia i Wyspy Samoa). Na końcu jest streszczenie w języku angielskim.

Za doniosłe osiągnięcie trzeba uznać następny katalog wydany pod redakcją Nadieżdy Pawłowny Czerkasziny wespół z T. Dołgodrową Каталог инкунабулов и палеотипов из собрания Генриха Клемма (Katalog inkunabułów i paleotypów ze zbiorów Henryka Klemma), Moskwa 2011. Klemm (1819-1886) był uważany za jednego z wielkich bibliografów XIX w. Obok zainteresowań zawodowych modą i publikacjami wielu prac jej poświęconych, był założycielem firmy wydawniczej w Dreźnie H. Klemms Verlag. Nade wszystko zasłynął jako kolekcjoner książek. Pozostawił po sobie 5 tysięcy rękopisów i książek z XV-XVIII w., a wśród nich 750 inkunabułów ${ }^{34}$. Znaczna część kolekcji znalazła się w Niemieckim Muzeum Książki i Pisma w Lipsku, skąd po wojnie została przewieziona do ZSRR. W kolekcji trofiejnych zbiorów było 137 inkunabułów i 4 paleotypy. Do nich dołączono 6 paleotypów i 1 starodruk Martyrologium Romanum Baroniusza, wydane w Rzymie w 1588 r. W sumie w tej kolekcji jest 148 pozycji. Przystępując do opracowywania tego katalogu, autorki wskazały, że pragną kontynuować prace nad inkunabułami zapoczątkowane przed wojną w Moskwie przez Kisielewa (Н.П. Киселев, Инвентарь инкунабулов Всероссийской библиотреки имени В И Лениина. Наличе на 01.01.1939, Moskwa 1939). Opisy bibliograficzne przedstawionych 148 eksponatów są podobne do opi-

${ }^{34}$ Н.П. Черкашина, Т.А. Долгодрова, Инкунабуль н палеотипь из собрания Генриха Клемма хранящиеся в Российсой государственной библиотеке, [в:] Каталог инкунабулов и палеотипов из собранния Генриха Клумма, Москва 2011, s. 11-12. 
sów w dwu poprzednich katalogach, z tym że przy nazwiskach typografów podane są daty ich działalności w danym mieście.

O ile z uznaniem można się odnieść do opracowania naukowego 148 eksponatów, co stanowi dokumentację produkcji wydawniczej książek w Europie w XV i po części w I połowie XVI w., to należy wytknąć autorkom prezentystyczne podejście przy opisywaniu ich ośrodków wydawniczych. Pomijają one bowiem fakt istnienia w tamtych czasach różnych drobnych państewek, a przyjmują obecny podział historyczny państw. Przez obranie uproszczonej klasyfikacji znikają z pola widzenia takie suwerenne wtedy organizmy państwowe, jak na przykład Wenecja czy Państwo Kościelne. Za to pojawiły się nieistniejące w tamtych czasach jako suwerenne organizmy takie państwa, jak Belgia czy Holandia (Нидерланды). Jednak na usprawiedliwienie autorek przemawia fakt, iż w tamtych czasach granice różnych państewek często się zmieniały. Stąd trudno się dziwić, że obrały one taką drogę na skróty, przedstawiając poszczególne ośrodki wydawnicze według dzisiejszego podziału politycznego. $\mathrm{Z}$ uwagi na fakt, że weryfikacja tego zagadnienia zajęłaby sporo czasu, w niniejszych rozważaniach ośrodki wydawnicze zostaną przedstawione w porządku podanym przez autorki.

Przy sporządzaniu tego katalogu autorki oparły się na wydanym w Dreźnie w 1884 r. katalogu Klemma Beschreibender Catalog des Bibliographischen Museums. Analizując poszczególne inkunabuły, autorki wyeksponowały 91 typografii z 9 - ich zdaniem - państw europejskich w XV w. (Niemcy - 71 książek wykonanych przez 41 typografii z 10 miast, Włochy - 37 książek, 29 typografii z 14 miast, Holandia - 7 książek, 5 typografii z 5 miast, Szwajcaria - 5 książek, 2 typografie z dwu miast, Francja - 3 książki, 3 typografie z Paryża, Belgia - 3 książki, 3 typografie z 3 miast, Hiszpania, Polska i Czechy po jednej książce). Natomiast, biorąc pod uwagę 10 paleotypów, autorki wskazały, iż 5 pochodzi z Niemiec, 3 z Włoch i 2 z Francji. Katalog daje przegląd drukarzy w XV w. w Europie. Nie sposób tu wymienić wszystkich, ograniczymy się do najważniejszych. Byli to: Jan Gutenberg (Moguncja), Johann Mentelin (Strasburg), Günther Zainer, Johann Schönsperger, Anton Sorg (Augsburg), Anton Koberger (Norymberga), Johann Zainer (Ulm), Konrad Fyner (Esslingen), Albrecht Kunne (Memmingen), Konrad Sweynheym i Arnold Pannartz (Subiaco), Ulrich Han (Rzym), Johann i Wendelin von Speyer, Aldus Manutius i Gabriel Giolitto di Ferrari (Wenecja), Nicolaus Laurentii (Florencja), Baldassarre Azzoguidi (Bolonia), Bartholomaeus de Valdezoccho (Padwa), Jan Kamp (Praga), Johann Amerbach i Michael Wenssler (Bazylea), Ulrich Gering, Martin Crantz, Michael Friburger (wszyscy trzej Paryż), Typographus „speculi” (Utrecht), Jacob van der Meer (Delft), Gerard Leeu (Gouda), Peter van Os (Zwolle), Caspar Straube (Kraków). W indeksie znalazły się jeszcze inne miasta, z których pochodzą książki nieznanych drukarzy. 
Dwa pierwsze opisy katalogu odnoszą się do książek ksylograficznych, a pozostałe do inkunabułów i 10 paleotypów z różnych krajów, z tym że wśród inkunabułów pod pozycją nr 98 znalazł się pomyłkowo starodruk wydany w $1586 \mathrm{r}$. Inkunabuły i paleotypy przedstawiono $\mathrm{w}$ kolejności według przyjętych przez autorki państw oraz ośrodków wydawniczych w obrębie tych państw. Przy państwach wymieniono ośrodki wydawnicze, a w nich drukarzy. W pierwszej kolejności przedstawiono Niemcy, z produkcją drukarską w Moguncji (poz. 3-24), Bambergu (poz. 25-26), Strasburgu (poz. 27-37), Kolonii (poz. 38-42), Augsburgu (poz. 43-74), Norymberdze (poz. 65-73), Esslingen (poz. 74), Ulm (poz. 74-78), Lubece (poz. 79-80), Memmingen (poz. 81), Frankfurcie n. Odrą (poz. 82-84). W dalszej kolejności są Włochy z produkcją w Subiaco (poz. 85-86), Rzymie (poz. 87-98), Wenecji (poz. 99-110), Mediolanie (poz. 111-112), Bolonii (poz. 113-115), Treviso (poz. 116), Ferrarze (poz. 117), Florencji (poz. 118-119), Mantui (poz. 120), Padwie (poz. 121), Pinerolo (poz. 122), Aquili (poz. 123), Chivasso (poz. 124) i Gaecie (poz. 125). Po Włoszech wymieniono Czechy z produkcją w Pradze (poz. 126). Kolejno Szwajcarię z produkcją w Bazylei (poz. 127-131). W następnej kolejności przedstawiono produkcję francuską (Paryż, poz. 132-137). Po Francji ukazano produkcję w Holandii (Utrecht albo Harlem poz. 138-140), Gouda (poz. 141), Deventer (poz. 142), Delft (poz. 143), Zwolle (poz. 144). Po tym miejscowości belgijskie: Alost (poz. 145), Louvain (poz. 146), Audenarde (poz. 147). Wreszcie jedną pozycję z Krakowa (poz. 148).

Prezentację każdego z egzemplarzy rozpoczyna opis bibliograficzny: nazwisko autora, tytuł dzieła, a w przypadku jego tłumaczenia na język obcy niekiedy również tytuł w tym języku wraz z nazwiskiem tłumacza. W dalszej kolejności występuje nazwisko typografa oraz miejsce i rok wydania. Po tym opisie bibliograficznym autorki podały dalsze informacje, kim byli autor dzieła oraz typograf. Następnie stosunkowo dużo uwagi poświęcono analizie zamieszczonych ilustracji (w wielu przypadkach podając ich reprodukcje), oprawom, znakom własnościowym występującym na oprawach. W niektórych opisach są również informacje, w jakich okolicznościach Klemm nabył omawiane dzieło. Na koniec autorki podały również sygnatury kompendiów bibliograficznych, w których zostało to dzieło opisane.

Nie sposób omówić wszystkich przypadków. Przykładowo można wymienić norymberskie wydanie poematu Teuerdank... z 1517 r. ilustrowane aż 118 drzeworytami do rysunków znanych niemieckich malarzy, a wśród nich Alberta Dürera. Autorki wyeksponowały 9 ilustracji, wśród nich 4 kolorowe (poz. 73); Historiae Alexandri Magni wydaną w Augsburgu w 1483 (poz. 59) zawiera 28 drzeworytów, spośród których autorki wybrały 13 kolorowych ilustracji, oraz florenckie wydanie Boskiej komedii Dantego z 1481 r. (poz. 118), które stanowi pierwszą edycję z dołączonym komentarzem włoskiego humanisty Christopherusa Landinusa, a grawiury do ilustracji tej książki zostały wykonane do rysunków Sandro Boticellego. 
W kolekcji Klemma spotykamy się z jednym z lepiej zachowanych na świecie pod względem estetycznym egzemplarzy Biblii, stworzonym przez znanego typografa z Moguncji Jana Gutenberga w 1454/5 r., jak również z fragmentami wydrukowanego przezeń w tym mieście dzieła Ars minior Donatusa Aeliusa z IV w., poświęconego zagadnieniom gramatyki łacińskiej. Studiując opisy poszczególnych dzieł, można poznać nazwiska różnych typografów, zaś na podstawie tytułów prezentowanych dzieł można zdobyć informację na temat problematyki, jaka interesowała wydawców książek XV w. Wśród różnych tytułów znalazło się 11 egzemplarzy Biblii różnych wydań i w różnych językach. Przede wszystkim Biblia łacińska Gutenberga, Moguncja 1454/5, czwarte wydanie Biblii łacińskiej w Moguncji w 1462 r. Dwa wydania w Strasburgu przed rokiem 1470 - jedno w języku łacińskim, drugie niemieckim, oraz dziewiąte wydanie Biblii w tym mieście po 1470 r., następnie wydanie augsburskie około 1475 r., będące czwartym wydaniem w języku niemieckim, a drugim posiadającym ilustracje; dalej wydanie niemieckie w Norymberdze, między rokiem 1476 a 1478, również niemieckie wydanie Kobergera w Norymberdze w 1483 r. Następnie Biblie w niemieckich dialektach - w dialekcie dolnych Niemiec, wydanie w Kolonii około 1478/9 r., nazywane Biblia kolońską. Inna Biblia w dialekcie dolnych Niemiec wydana w Lubece w 1494 r., nazywana Biblią lubecką. Biblia w dialekcie Dolnej Saksonii wydana w Kolonii około 1478/9, nazywana również Bibliq kolońską. Wreszcie Pięcioksiąg w języku hebrajskim, wydany w Bolonii w 1482 r.

Przedstawione inkunabuły i paleotypy odnoszą się do różnych zagadnień. Tak więc możemy mówić o encyklopedycznym słowniku Catholicon stworzonym przez dominikanina Johannesa Balbusa w XIII w., wydanym w Moguncji w 1460 r., a także kompendium poświęconym leksykografii Lexicon Graecorum, wydanym pod redakcją Demetriusa Chalcondylasa w Mediolanie w 1499 r. Spotykamy się z dziełami autorów starożytnych, zarówno pogańskich, jak i chrześcijańskich: św. Augustyna: De civitate Dei, Subiaco 1467 oraz Wenecja 1470; św. Ambrożego: Opera, Bazylea 1492; Cycerona: De officiis..., Moguncja 1466, a także Paryż 1471/2, De oratore..., Subiaco 1465, Cato maior de senectute..., Rzym 1469, Cato maior de senectute..., Rzym ok. 1469, Tusculane disputationes, Rzym 1469; Laelius de amicitia..., Rzym 1469, Paradoxa stoicorum..., Rzym 1464, Epistolae ad familares..., Wenecja 1471, Orationes, Mediolan ok. 1478; Diodora Sycylijskiego: Bibliotheca..., Bolonia 1472; Plutarcha: Vitae illustrium virorum..., Aquila 1482; Tacyta: Opera, Wenecja ok. 1471/2; Valeriusa Maximusa Caiusa: Facta et dicta memorabiulia, Moguncja 1471; Laktancjusza: Carmen de resurrectione dominica, Frankfurt n. Odrą 1507, Opera, Rzym 1468 oraz Rzym 1474; Hygianusa Caiusa Iuliusa: Poeticon astronomicon, Wenecja 1488; Ovidiusa Naso Publiusa: Metamorfoses, Pinerolo 1480; Terentiusa Afer Publiusa: Comediae, Paryż 1499; Jana Chryzostoma: Homiliae super Johannem, Rzym 1470. 
Z dzieł współczesnych pisarzy można wymienić Dantego: La commedia, Florencja 1481; Giovanniego Boccaccia: De claris mulieribus w tłumaczeniu niemieckim, Ulm 1473; Lodovica Ariosta: Orlando furioso, Wenecja 1544 oraz Cinque canti..., Wenecja 1544; Baptisty Montuanusa: In Robertum Severinatem panegiricum carmen..., Bolonia 1489; Franciscusa Columny: Hypnerotomachia Poliphili..., Wenecja 1499; niemieckiego poematu Teuerdank..., wydanego w Norymberdze w 1517 oraz Augsburgu w 1519 r. Niektórzy twierdzą, że poemat ten był napisany z rozkazu cesarza Maksymiliana I, a inni, że przez niego samego.

Kolekcja Klemma zawiera dzieła poświęcone medycynie i farmacji, astronomii i astrologii. Jest w niej traktat przypisywany włoskiemu lekarzowi i chirurgowi z XIII w. Guglielmo da Saliceto zatytułowany De salute corporis... wydany w Utrechcie bądź Harlemie w 1472 r. Z dzieł poświęconych farmacji można wymienić Herbarius wydany w Moguncji w 1484 r. w języku łacińskim, zwierający nazwy 248 roślin w języku łacińskim i niemieckim. Inny zielnik Hortus sanitatis wydany w języku niemieckim również w Moguncji w 1491 r. także zawiera nazwy 530 roślin, 164 zwierząt, 122 ptaków, 106 ryb i 144 minerały, opisane w języku łacińskim i niemieckim. Następnie w 1485 r., również w Moguncji, pod tym samym tytułem ukazało się dzieło niemieckojęzyczne (nazywane małym zielnikiem). Wreszcie w Moguncji w 1491 r. Jakob Meydenbach wydał pod takim samym tytułem dzieło łacińskojęzyczne, które zawiera opis ponad tysiąca roślin, zwierząt, ptaków i ryb. Są bogate ilustracje. Grawiury obejmują 530 widoków roślin, 164 zwierząt, 122 ptaków, 106 ryb oraz 144 minerałów. Astronomii poświęcono dzieło niemieckiego astronoma żyjącego w XV-XVI w. Eberharda Schleusingera: De cometis, wydane w $1472 \mathrm{r}$. w Beromünster, a także tłumaczenie $\mathrm{z}$ języka arabskiego na łacinę dzieła żyjącego w IX w. arabskiego astrologa Albumascara noszące tytuł Flores astrologiae, które zostało wydane w Augsburgu w 1488 r.

Katalog zawiera również opisy innych wydawnictw, jak różnego rodzaju mszały, modlitewniki, zwłaszcza maryjne i do różnych świętych, martyrologię i żywoty świętych, a wśród nich Złotą legendę (Legenda aurea) Jakuba Voragine’a wydaną w języku niemieckim w Norymberdze w 1475 oraz w Pradze w języku czeskim w 1495 r., rozważania teologiczne i homilie, kroniki i opisy podróży, kalendarze oraz poradniki. Jakkolwiek główną intencją autorek tego katalogu było wyeksponowanie walorów artystycznych książek wydawanych w XV i I połowie XVI w., to katalog jest również cennym kompendium bibliograficznym, wskazującym na książki tłoczone w różnych oficynach Europy w XV, a także częściowo do połowy XVI w.

Jak przystało na dział muzeum książki, autorki tego katalogu w swych opisach zwracają więcej uwagi na walory artystyczne omawianych publikacji, co dla znawców sztuki ma znaczenie pierwszorzędne; niezależnie od tego dla historyków książki ważną rolę odgrywają zagadnienia księgoznawcze. Zważywszy, że w kolekcji 
Klemma znalazły się książki tłoczone w różnych typografiach Europy poświęcone różnorakim kwestiom, w sposób wybiórczy zwrócono uwagę na ten aspekt.

Tak samo nie sposób omówić wszystkich aspektów związanych ze stroną artystyczną książek. Przykładowo można wymienić Historiae Alexandri Magni wydaną w Augsburgu w 1483 r. (poz. 50). Zawiera ona aż 13 kolorowych ilustracji. Podobnie wydane w tym mieście w roku 1483 dzieło Ulricha von Richentala (poz. 51) poświęcone soborowi w Konstancji Concilium zu Constanz zawiera aż ponad 1200 grawiur, spośród których 10 zostało wyeksponowanych w tym katalogu. Natomiast wydrukowany przez Johanna Schönspergera w Norymberdze w 1517 r. paleotyp Teuerdank... (poz. 73) zawiera aż 118 grawiur wykonanych do rysunków znanych w tym czasie niemieckich malarzy. Można też wskazać wspominane uprzednio florenckie wydanie Boskiej komedii Dantego z 1481 r. (poz. 118).

W latach 2015-2016 w ramach serii „Коллекции Российской государственной библиотеки" wydano pod redakcją T. Dołgodrowej w Moskwie na razie dwie części czwartego już z rzędu katalogu zatytułowanego Каталог переплетов Якоба Краузе и мастеров его круга, a trwają dalsze prace nad wydaniem jego trzeciej części. W niniejszych rozważaniach obydwie części katalogu zostaną potraktowane jako całość. We wstępach do obu części znajdujemy informacje, iż celem tej publikacji jest pokazanie walorów artystycznych opraw wykonanych przez Jakuba Krauzego i jego naśladowców. Wstęp do części pierwszej podaje ogólne informacje dotyczące europejskiego renesansowego introligatorstwa. Odwołując się do opracowania H. Loubiera: Der Bucheinband von seinen Anfängen bis zum Ende des 18. Jahrhundets, Leipzig 1926, Dołgodrowa stwierdziła, iż książki z renesansowymi oprawami wykonanymi przez Jakuba Krauzego i jego zwolenników aż do zakończenia II wojny światowej w dużej części znajdowały się w Sächsische Landesbibliothek w Dreźnie, w Centralnym Archiwum Państwowym (Hauptstaatsarchiv) tego miasta, a także w bibliotece Gimnazjum Drezdeńskiego. Pojedyncze zaś ich egzemplarze można było spotkać w różnych miejscowościach: Darmstadt, Hamburg, Kolonia, Monachium, Wolfenbüttel, Freiburg, Kopenhaga, Wiedeń, Lipsk (Deutsche Buch- und Schriftmuseum), Berlin (Państwowa Biblioteka oraz Pałacowe Muzeum Sztuki Stosowanej (Музей Прикладного исскуства), a także w kolekcjach prywatnych. Jednakże największą ich liczbę około 1200 egzemplarzy posiadała kolekcja Sächsische Landesbibliothek. Po roku 1945 sporą jej część przemieszczono do ZSRR, tak że obecnie w bibliotece tej pozostało zaledwie około 300 egzemplarzy.

Podstawową literaturę przedmiotu wykorzystaną przez autorkę w obydwu częściach katalogu stanowią opracowania Christiana Schmidta: Jacob Krause. Ein Kursägshiser Hochbuch binder des 16 Jahrhunders, Leipzig 1923 oraz Konrada von Rabenau: Deutsche Bucheinbände der Renaissance um Jacob Krause - Hofbuchbindere des Kurfürsten August I. Von Sachsen, Unter Mitwirkung von Susanne Rothe und 
Andreas Wittenberg, Bd. I, II, Brűssel-Bruxelles, Bibliotheca Wittockiana, Schöeneiche 1994. Studiując detale poszczególnych opraw, wzięła pod uwagę ustalenia wymienionych badaczy. Pod koniec wstępu w obydwu częściach podała również inne najważniejsze pozycje ${ }^{35}$.

Autorka zamieściła życiorysy elektora saskiego Augusta I (1526-1563), założyciela biblioteki drezdeńskiej, mającej początkowo swą siedzibę w Annaburgu, przybierającej z upływem czasu różne nazwy oraz jego żony księżniczki duńskiej Anny, a także dwóch introligatorów: Jakuba Krausego i Kaspra Mousera. Dokonała również charakterystyki pierwszego katalogu tej biblioteki z roku 1574 nazywanego Registratur der bucher in des Churfusten zu Saxen liberey zur Annaburg. Na podstawie opracowania Franka Auricha: Registratur der bucher in des Churfursten zu Saxen liberey zur Annaburg 1574, Der erste Katalog der bibliothek des Kürfursten August, Faksimile und transkription, Dresden 2010, stwierdziła, iż katalog ten zawierał opisy 1721 tomów, podzielone na działy, a te z kolei na podrzędne jednostki ${ }^{36}$. Wzmiankowała również o innym katalogu z roku 1580, według którego

${ }^{35}$ Poza wymienionymi dwiema pozycjami podała następującą literaturę: Elizabeth (Ilse) Schunke, Die Jacob Krause - Ausstellung des Sächs Landesbibliothek zu Dresden, Jahrbuch der Einbandkunst 1927, Leipzig 1927; eadem, Krause-Studien, Harrassowitz-Leipzig 1932; eadem, Die Jacob Krause Ausstellung des Sächs. Landesbibliothec zu Dresden (Jahrbuch der Einbandkunst 1927), Leipzig 1927; eadem, Krausse-Studien, Harrasowitz, Leipzig 1932; eadem, Leben und Werk Jacob Krauses, Leipzig 1943; eadem, Ein Meisterwerk der Buchbindekunst des XVI Jahrhunders im bibliotethecsbestand der Bergacademie, Freiburg 1973; eadem, Einfüng in die Einhandbestimmung, Dresden 1977; Frank Aurich, Registratur der bucher in des Churfursten zu Saxen liberey zur Annaburg 1574, Der erste Katalog der bibliothec des Kürfursten August, Faksimile und transkription, Dresden 2010. Wreszcie swoje artykuły; jeden wespół z Frankiem Aurichem: Les reliures de Jacob Krause, „Bulletin du Bibliophile”, Paris 2006, drugi opublikowany w „Наше Наследие” 1999, no. 49: Коллекция переплетов Якоба Краузе в РГБ oraz trzeci w wydawnictwie UMCS w 2004 r.: О создании каталога собрания Якоба Краузе и его круга. Poza tym w wykazie wykorzystanej literatury wymienia jeszcze inne pozycje. We wstępie do drugiej części wymieniła zaledwie 3 pozycje literatury podawane w części I oraz jedną najnowszą - artykuł opublikowany w Sankt Petersburgu z 2012 r.

${ }^{36}$ Największy dział teologiczny składał się aż z 29 jednostek. Za nim na miejscu następnym był dział historyczny składający się z 12 jednostek zawierających opisy turniejów i obrzędów ( katalogów frankfurckich jarmarków książek, historii państwa moskiewskiego. W następnych działach opisano książki poświęcone kosmografii; książki z opisami komedii Terencjusza; książki z opisami bajek Ezopa; książki dotyczące sztuki wojennej; książki poświęcone ujeżdżaniu koni; książki poświęcone ornitologii; książki zawierające opisy różnych działów medycyny wraz z farmacją; książki poświęcone filozofii; książki poświęcone zagadnieniom sztuki, uwzględniające również rytownictwo i iluminację książek, książki dotyczące mineralogii; książki poświęcone alchemii; książki poświęcone prawu; książki poświęcone matematyce; książki poświęcone geometrii; książki poświęcone astronomii; książki poświęcone architekturze; książki poświęcone astrologii; książki poświęcone technice ogrodniczej; książki poświęcone agronomii i prowadzeniu gospodarstwa domowego (домоводсто). Ponadto wzmianka jest o łacińskojęzycznym rejestrze w tym katalogu książek poświęconych teologii, filozofii, medycynie, prawu i astronomii. 
znajdowały się tam opisy 2354 tomów, zaś z opracowania Christophera Schmidta, Jacob Krause. Ein Kursägshiser Hochbuch binder des 16 Jahrunders, Leipzig 1923 wynika, że było ich $2595^{37}$.

Kompozycja obydwu części katalogu Krauzego jest nieco podobna do omawianego wcześniej katalogu Bechera, choć bardziej rozbudowano w nim część opisującą same oprawy. Dołgodrowa w części pierwszej poza wstępem wyodrębniła w katalogu rozdziały, którym można dać roboczą numerację: 1) Oprawy wykonane przez Jakuba Krauzego w latach 1566-1585; 2) Oprawy Jakuba Mausera z lat 1578-1593; 3) Oprawy wykonane przez Jakuba Weidlicha w latach 1551-1566; 4) Oprawy wykonane przez Urbana Köblitza w 1574 r.; 5) Oprawy wykonane przez mistrzów z kręgu Jakuba Krauzego w latach 1595-1616. Natomiast w odniesieniu do części drugiej katalogu można wymienić roboczo następujące rozdziały: 1) Oprawy wykonane przez Jakuba Krauzego w latach 1566-1585;2) Oprawy wykonane przez Jakuba Mausera w latach 1578-1595;3) Oprawy wykonane przez Jakuba Weidlicha w latach 1551-1561. W odróżnieniu do części pierwszej nie spotykamy w tej części informacji o oprawach wykonanych przez Urbana Köblitza, lecz umowny rozdział czwarty stanowią tu informacje o oprawach wykonanych przez mistrzów z kręgu Jakuba Krauzego w latach 1595-1616. Następny quasi-rozdział piąty poświęcono oprawie wykonanej przez Severina Röttera, a umowny rozdział szósty oprawie wykonanej przez Thomasa Krügera. W obydwu częściach katalogu niektóre z tych umownych rozdziałów są podzielone na drobniejsze podrozdziały ze względu na techniki wykonania opraw, czy też na materiały stosowane do sporządzania opraw i ich pokrywania ${ }^{38}$.

Tatiana Dołgodrowa wskazała, iż okres renesansu w zachodniej Europie wprowadził do introligatorstwa wiele nowych metod w technice dekorowania opraw, czego nie można będzie zaobserwować w wiekach następnych. W szczególności pojawiły się jednolite treściowo ryciny wyciskane przy pomocy wałka (tzw. rollek), przyjmujące nazwę od niemieckiego pojęcia rolle. W odniesieniu do tego typu rycin o charakterze religijnym używa pojęcia salvatorrole. Stwierdziła też, iż na oprawach zaczęły się pojawiać superekslibrisy - inicjały, monogramy, herby właścicieli książek,

37 Т.А. Долгодрова, Вступная статия, [в:] еadem, Каталог переплетов Якоба Краузе и масреров его круга, Ч. 1, Москва 2015, s. 16-17; еadem, О собрании переплетов Якоба Краузе и мастеров его круга, хранясчихся в российской государственной библиотеке, [в:] Каталог художественных переплетов собрания Карла Бехера, Ч. 2, Москва 2016, s. 9-16.

${ }^{38} \mathrm{~W}$ pierwszej części wymieniła następujące grupy opraw: 1) obleczone cielęcą skórą ze złotymi wyciskami; 2) obleczone pergaminem ze srebrnymi wyciskami; 3) obleczone tkaniną ze ślepymi wyciskami; 4) obleczone skórą ze złotymi wyciskami oraz barwione farbami olejnymi; 5) obleczone pergaminem ze złotymi wyciskami. Natomiast w części drugiej wymieniła: 1) oprawy obleczone skórą ze złotymi wyciskami; 2) obleczone pergaminem ze złotymi wyciskami; 3) oprawy obleczone skórą ze złotymi wyciskami, barwione farbami olejnymi; 4) oprawy obleczone skórą ze złotymi wyciskami. 
wyobrażenia scen biblijnych ze Starego i Nowego Testamentu, figury alegoryczne (rozsądku, praworządności, miłosierdzia, wiary, fortuny itp.), portrety klasyków antyczności: Cycerona, Wergiliusza i Owidiusza oraz ich bohaterów. W Niemczech, gdzie szczególnie było to widoczne, drzeworyty z wyobrażeniami tego typu wykonywali tacy mistrzowie, jak Jost Amman i Wergil Solis. Rolki wittenberskie wykonywane do rysunków Lucasa Cranacha młodszego zawierały przede wszystkim portrety działaczy reformacji. Przy nich znajdowały się skrócone napisy takich nazwisk, jak: Martin Lut[er], Philip Mela[nchton], Erasmus Ro[therdamus], Ioanni HVS, jak też szyfry odsyłające do sekwencji biblijnych.

Na podstawie znaków pozostawionych przez introligatorów na oprawach autorka w pierwszym rzędzie wymieniła wśród posiadaczy książek elektora Augusta I, podającego tytuły książek, które z całą pewnością należały do niego, jak również te, o których przynależności można tylko domniemywać. To samo czyni w odniesieniu do książek jego żony Anny - córki króla duńskiego Christiana III (1532-1585). Ponadto wyodrębniła trzecią grupę książek będących wspólną własnością małżonków. W dalszej kolejności opisała księgozbiory ich dzieci: syna Christiana I, elektora saskiego, wskazując jego własny księgozbiór, jak również wspólny z żoną Zofią - córką elektora brandenburskiego oraz córki Doroty, księżniczki saskiej. Po tym wymieniła książki następnego pokolenia: synów elektora Christiana I - Hansa Georga oraz Christiana II, wreszcie Fryderyka Wilhelma I, elektora sasko-weimarskiego i regenta Christiana II. Przynależność książek do określonego typu właścicieli autorka ustaliła na podstawie znaków występujących na oprawach, przede wszystkim herbów oraz inicjałów właścicieli, monogramów introligatorów, pieczęci oraz sygnatur. Oprawy nosiły pieczęcie: Bibliotheca Regia Dresdensis; HERZOGL; ANHALT BEHÜRDEN-Bibliothec Dessau; A. SCHACHTAFABEL KÖNIGL. HOFBUCHBINDER DRESDEN; ekslibrisy: Bibliotheca Electoralis publica. C. F. Holtzman. Fec. Dresden, Hainzemaier Nachf. (A. Schachachabel) Buchbinderei Dresden.

Jakkolwiek w katalogu strona opisowa opraw zdecydowanie przeważa nad podawanymi tytułami, to może on stanowić doskonałe źródło dotyczące drukarstwa w XVI w. w Europie, a zwłaszcza Rzeszy Niemieckiej, szczególnie w kręgach protestanckich. Wśród omawianych książek zdecydowaną większość stanowi literatura religijna propagująca luteranizm, ale też w niewielkim stopniu występują dzieła dotyczące katolicyzmu, jak np. reguła św. Benedykta, rozważania ascetyczne Tomasza à Kempis czy z historii Kościoła. Jest też Koran w tłumaczeniu Lutra. Stosunkowo duża jest liczba tytułów różnego rodzaju wydawnictw słownikowych, a także literatury pięknej poszczególnych okresów, zwłaszcza renesansu, drukowanej w różnych krajach. Znajdują się książki poświęcone medycynie, farmacji i związanej z nią botanice. Występują tytuły poświęcone weterynarii i ujeżdżaniu koni. Pojawiają się także tytuły poświęcone matematyce, buchalterii, geografii, kartografii, astronomii 
i astrologii; dzieła poświęcone sztuce wojennej, fortyfikacjom i technice; jest wiele tytułów dzieł historycznych, pisarzy antycznych, ale i okresu późniejszego. Znajdują się dzieła poświęcone zagadnieniom prawno-ustrojowym, w tym książka autora polemizującego z Niccolo Machiavellim. Znajdujemy tytuły poświęcone wychowaniu dzieci i młodzieży, poradniki dotyczące sposobu życia kobiet w okresie przedpołogowym, jak również w trakcie pielęgnacji niemowląt. Wreszcie trzeba wspomnieć o kalendarzach i książkach kulinarnych. Jest także album zawierający ilustracje do Biblii Solisa Vergila (1514-1562). Same tylko wymienienie tytułów stanowiłoby doskonałą ilustrację kultury książki w tamtych czasach.

We wstępie do części pierwszej katalogu Tatiana Dołgodrowa poinformowała, iż przedstawiono w nim wyniki badań poświęconych 381 oprawom wykonanym przez Jakuba Krauzego oraz jego naśladowców. Znajdują się one obecnie w specjalnej komnacie Muzeum RGB. Ze względu na sporą liczbę złotych wycisków na nich, stwierdziła, iż ten fond można bez obawy nazywać złotym fondem RGB. Ponadto wspomniała o innym fondzie tej biblioteki - Oddziale Rzadkiej Książki XVI wieku, w którym znajduje się około 400 tego typu rozproszonych opraw. Można domniemywać, iż pochodzą one z różnych miejscowości Niemiec. Natomiast we wstępie do części drugiej stwierdziła, że z Oddziału Rzadkiej Książki XVI wieku badaniom poddała 234 opraw, a wyniki badań poświęcone następnym opublikuje w trzeciej części tego katalogu. Biorąc pod uwagę powyższe dane liczbowe, można sądzić, że Dołgodrowa zbadała łącznie 615 opraw (381 plus 234). Jednak przebadanych opraw jest więcej, gdyż pewne tytuły składały się nawet $\mathrm{z}$ kilku tomów posiadających swe oprawy $^{39}$. Natomiast odnośnie do tytułów druków wymienionych w obu częściach katalogu można sądzić, że jest ich 615. Jednak i tę liczbę też trzeba skorygować, gdyż Dołgodrowa wprowadziła do rejestru tylko jeden tytuł oprawy, nie włączając doń konwolut, a ich w pewnych oprawach mogło być nawet kilka, pomimo iż pod opisem bibliograficznym głównego tytułu dawała także ich tytuły. Tego typu przypadków w części pierwszej jest 63, a w drugiej 74. Zatem gdy do liczby 615 tytułów opisujących oprawy dodamy 65 tytułów konwolut z pierwszej części oraz 74 z drugiej, to otrzymamy łączną liczbę 752 tytułów.

Należy też nadmienić, iż w tej bogatej kolekcji tytułów znajdują się trzy poloniki. Są to niemieckojęzyczne dzieło Andrzeja Frycza Modrzewskiego: Von Verbesserung des Gemeinen Nutz finff Bucher Andrei Fritti Modrevii..., Bazylea 1557 z oprawą

39 Można tu na przykład wymienić dzieła Marcina Lutra wydane w Wittenberdze w latach 1552 62 mające aż sześć opraw (kr. 29); Biblia łacińsko-niemiecka, Wittenberga 1565, mająca 10 opraw (kr. 40), Homilie poświęcone Ewangeliom na niedziele Georga Mieiera z Norynbergi mające 7 opraw (kr. 157), Dzieła Marcina Lutra wydane w Jenie w latach w 1572-81, 81, 63, 84 mające wraz ze skorowidzem dziewięć opraw. Podobnych przykładów jest znacznie więcej. 
wykonaną przez Krauzego mającą napis Kranz oraz cztery salvatorrole - z wizerunkiem Chrystusa błogosławiącego, św. Piotra, św. Pawła oraz św. Jana Chrzciciela. Pod wizerunkiem Chrystusa jest napis: Data Est Mihi Omn[ia potentia]. Dwa następnie poloniki to dzieła Marcina Kromera: Polonia sive de situ, populis, moribus, magistratibus et republica regni Polonici libri duo..., Kolonia 1578 oraz Martini Cromeri De origine et rebus gestis Polonorum libri XXX, Bazylea 1555. Obie oprawy zostały wykonane przez Jakuba Krauzego w stylu wittenberskim. Pierwsza zawiera inicjał IK (Jakub Krauze), cztery profilowane portrety Lutra, Melanchtona, Husa i Erazma z Rotterdamu, a pod nimi wytłoczone napisy: MARTIN LUT[her], PHILIP[p] MELA[nchton], ERASMUS RO[terodamus], JOANNI[es] HVS, dwa herby - elektora saskiego, a poniżej jego herb duński, pod którym jest wycisk: ANNA GEBORNE AUS KONGLICHE[m] STAM[m] ZV DEMMARCK HERZOGIN ZV SAXEN KV[rfürstin]. Na drugiej oprawie wytłoczone zostały cztery salvatorrole: Chrystusa błogosławiącego, króla Dawida, św. Pawła i św. Jana Chrzciciela. Pod wizerunkiem Chrystusa występują litery: DATA EST MIHI (omnes potentia) Mat. 28, 18.

Opracowywanie przez Muzeum Książki przy Państwowej Bibliotece Rosji zbiorów przejętych z Niemiec po II wojnie światowej stanowi nie lada przygodę intelektualną dla badaczy tych zasobów. Zdobywają oni bowiem nowe informacje, na podstawie których weryfikują, względnie poszerzają dotychczasowe swe ustalenia. Jest to szerokie zagadnienie. Można tu podać nieliczne przykłady. I tak, Dołgodrowa w roku 2012 (Kultura, historia, książka, s. 181) pisała, że w Muzeum Książki znajduje się wydane w Sewilii w 1549 dzieło Amadisa de Gaula, po czym w roku 2017 w katalogu Bechra (s. 161, poz. 176) dokonuje opisu tej książki, by w wydanej w roku 2019 II części katalogu Klemma (s. 79, nr 489) wskazać, że w Muzeum Książki znajduje się jej tłumaczenie niemieckie wydane w Augsburgu w 1578 roku.

Jak się wydaje, poszczególne katalogi były tworzone stosownie do struktury zasobów zlokalizowanych w Muzeum Książki. Stąd też, pomimo że autorka w artykule opublikowanym w 2002 roku (Kultura, historia, ksiażka) pisała o rzadkich dziełach znajdujących się w zbiorach Państwowej Biblioteki Rosji, to nie podaje niektórych ich tytułów w wydanych katalogach. Oznacza to, że są one w innych zespołach i w dalszych badaniach zostaną ukazane. Przyjęcie określonego sposobu numeracji jest temu podporządkowane. Oddzielną numerację mają przedstawiane dzieła wymieniane w poszczególnych katalogach, lecz strony podawanych w nich opraw są zupełnie inne. Na przykład wspominany w tekście włoski rękopis Diktysa z Krety z 1499 roku, ze względów artystycznych De bęllo Troiano... w katalogu Bechera ma numer 368, ale według paginacji książkowej jest na stronie 315. Odnosi się to do wszystkich pozycji wymienianych w poszczególnych katalogach.

Trudnością dla czytelnika spoza Federacji mogą być przekształcone na sposób rosyjski nazwiska autorów, drukarzy i wydawców, jak ma przykład nazwisko dru- 
karza Meya na Mema. Mogą się pojawić zarzuty, że podawane przez wydawców opisy bibliograficzne wymienianych dzieł $\mathrm{w}$ katalogach są niezgodne $\mathrm{z}$ opisami występującymi w internecie. To jednak wymagałoby drobiazgowego i długotrwałego sprawdzania. O walorach poznawczych katalogów dla historyków kultury, książki, bibliologów i czytelników znajdujemy informacje na kartach niniejszego artykułu. Jednak dla historyków sztuki niniejsze rozważania mają znaczenie drugorzędne. Niemniej jednak bardzo ważne są pogłębione badania dotyczące strony artystycznej prezentowanych dzieł i ich opraw. Trzeba podkreślić, że porównywane są ze sobą egzemplarze znajdujące się w Muzeum Książki Państwowej Biblioteki z egzemplarzami zachowanymi w różnych miejscach świata.

\section{Bibliografia}

Бородин О.Р., Долгодрова Т.А., Коллекиия Немеизкого музея книги и шрифта в собрании Российской государственной библиотеки, „Наше Наследие” 1994, № 32, s. 98-105. Черкашина Н.П., Долгодрова Т.А., Инкунабулы н палеотипы из собрания Генриха Клемма хранящиеся в Российсой государственной библиотеке, [в:] Каталог инкунабулов и палеотипов из собранния Генриха Клемма, Москва 2011.

Долгодрова Т.А., Доктор Карл Бехер и его собрание исторических переплетов, [в:] Каталог художественных переплетов собрания Карла Бехера, Москва 2007, s. 9-24. Долгодрова Т.[А.], Испанские кнжные редкости XV-XVI вв. хранящеся в РТГ, [w:] Kultura, historia, książka. Zbiór studiów, red. A. Dymmel, B. Rejakowa, Lublin 2012, s. $175-181$.

Долгодрова Т.А., Каталог набивных тканей XIII-XIX веков собрания Роберта Форрера, Москва 2010.

Долгирова Т.А., Каталог художественных переплетов собрания Карла Бехера, Москва 2007.

Долгодрова Т.А., Каталог переплетов Якоба Краузе и масреров его круга, Ч. 1, Москва 2015, Ч. ІІ, Москва 2016.

Долгодрова Т.А., Немецкая и Нидерландская книга XV века. (Пробемы взаимовлияния и национальные особенности), Москва 2000.

Долгодрова Т.А., О собрании переплетов Якоба Краузе имастеров его круга, хранясчихся в российской государственной библиотеке, [в:] Каталог художественных переплетов собрания Карла Бехера, Ч. I, Москва 2015, s. 9-40.

Долгодрова Т.А., О собрании переплетов Якоба Краузе имастеров его круга, хранясчихся в российской государственной библиотеке, [в:] Каталог художественных переплетов собрания Карла Бехера, Ч. II, Москва 2016, s. 9-16.

Долгодрова Т.А., О собрании набивных тканей ХІІІ-ХІХ веков Роберта Форрера, [в:] Каталог набивных тканей XIII-XIX веков собрания Роберта Форрера, Москва 2010, s. 9-29. 
Долгодрова Т.А., Уникальные западноевропейское печатаные книги XV-XVI веков из трофейного собрания Российской государственной библиотеки, „Наше Наследие” 1997, № 42, s. 113-119.

Grimsted Kennedy P., Dwukrotnie zrabowane i nadal z dala od ojczyzny. Losy trzech bibliotek słowiańskich przejętych przez nazistów w Paryżu, „Archeion” 2003, t. 106, s. 47-84.

Grimsted Kennedy P., The Odyssey of the Turgenev Library from Paris, 1940-2002. Books as victims and trophies of war, Amsterdam 2003.

Grimsted Kennedy P., Twice plundered, but still not home from the war. The fate of three Slavic libraries confiscated by the Nazis from Paris, „Solanus” 2002, vol. 16, s. 39-76.

Гринстед Кеннеди П., Трофейные книги из Западной Европы: Дорога в Минск через Ратибор (Рацибуж), [в:] Матэрыялы Трэиіх Міжнар. Кнігазнауучых чытанняу „Кніга Беларусі: Повязь часоў” (Мінск, 16-17 верасня 2003 г.), склад. Т.І. Рошчына, Мінск 2005, s. 39-90.

Котрелев Н.В., Плач о погибели русской библиотеки, [в:] Редкие книги и рукописи. Изучение и описание. Материалы Всесоюзного совещания заведующих отделами редких книг и рукописей библиотек вузов. Ленинград, 24-26 января 1989 г., ред. Н.И. Николаев, Ленинград 1991, s. 94-97.

Krawczyk A., Katalog nabiwnych tkanij XIII-XIX viekow sobranija Roberta Forrera, Moskwa 2010, „Res Historica” 2012, nr 33, s. 266-274.

Krawczyk A., Ksiażki z oprawami artystycznymi z kolekcji Carla Bechera w Państwowej Bibliotece Rosji, [w:] Z ksiażką przez życie, red. A. Krawczyk, Lublin 2008, s. 191-206.

Krawczyk A., Studia nad ksią̇kami przemieszczonymi z Europy do ZSRR po II wojnie światowej, [w:] O etosie książi. Studia z dziejów bibliotek i kultury czytelniczej, red. T. Wilkoń, Katowice 2017, s. 99-123. 